\title{
Lithostructural and Petrochemical Survey of Djarkadougou Gold Prospect (South West Burkina Faso / West Africa)
}

\author{
Yao Honoré Koffi ${ }^{1}$, Sagbrou Chérubin Djro $^{2}$ \& Urbain Wenmenga ${ }^{1}$ \\ ${ }^{1}$ Laboratoire de Géoressource, Université Ouagadougou I Pr. Joseph Ki-Zerbo, Ouagadougou, Burkina-Faso \\ ${ }^{2}$ Laboratoire de Géologie du Socle et de Métallogénie, Université Felix Houphouët Boigny, Abidjan, Côte \\ d'Ivoire \\ Correspondence: Yao Honoré Koffi, Laboratoire Géosciences-Géoressources, Université Ouagadougou I Pr. \\ Joseph Ki-Zerbo, 03 BP 7021 Ouagadougou 03 UFR/SVT, Burkina-Faso. Tel: 226-7898-0077. E-mail: \\ yaohonorekoffi@gmail.com
}

Received: November 8, 2016

Accepted: November 19, 2016

Online Published: February 6, 2017

doi:10.5539/esr.v6n1p155

URL: http://dx.doi.org/10.5539/esr.v6n1p155

\begin{abstract}
The Djarkadougou gold prospect is located on the Birimian greenstone belt of the Houndé exploration permit held by the company Orezone Inc. The permit is at $275 \mathrm{~km}$ far from the capital Ouagadougou south- western Burkina Faso, West Africa. This area is based on sheared and metamorphosed greenschist facies rocks. Metamorphism locally reaches to the amphibolite facies around intrusions. There are two major lithological units whose interface is marked by a NW-SE trending shear corridor: an unit of andesite-basaltic rocks of andesitic breccias in the East and volcaniclastic and sedimentary unit composed flows, tuffs and felsic to mafic breccia, interbedded volcano-sedimentary rocks. All this together is intruded by plutonic rocks, and various felsic to mafic dykes. These rocks have undergone ductile to brittle heterogeneous deformations and hydrothermal alteration sericite \pm carbonate \pm quartz \pm sulphide within deformation corridors. The rocks of the East and West domains affected by three phases of brittle-ductile deformation (D1, D2, and D3) and the meteoric alteration is systematic in superficial facies of Djarakadougou core drilling.Geochemical analysis shows a tholeiitic to calc-alkaline volcanic serie characteristic a bimodal volcanism. The spectra of normalized REE chondrites are generally flat and constant reminding those of N-MORB basalt. The chemical compositions of andesite and basalt are deferred on several discrimination diagrams especially $\mathrm{Th} / \mathrm{Yb}-\mathrm{Nb} / \mathrm{Yb}$ and $2 \mathrm{Nb}-\mathrm{Zr} / 4-\mathrm{Y}$ show that andesites and basalts of the prospect are issued in geotectonic setting of volcanism preponderant arc.
\end{abstract}

Keywords: Djarkadougou, Houndé, shear-zone, volcano-sedimentary, hydrothermal, tholeiite, calc-alkaline, mylonite, blastomylonite, Birimian.

\section{Introduction}

\subsection{Introduction}

The West African craton lies on metamorphosed and granitized basement definitely stabilized around $1700 \mathrm{Ma}$. We distinguish in this craton two major shield called Leo in the South and Reguibat in the North. The Paleoproterozoic formations occupy the Baoule-Mossi domain to the east of west Archean representing Kénéman-Man domain. This shield, are separated usually by a major tectonic contact (Figure.1), the fault Sassandra. Burkina Faso belongs to the eastern part of the ride of Leo and precisely the domain where Baoule-Mossi built formations during the Eburnean orogeny (2250-2100 Ma) are organized in greenstone belts of NE-SW and NNE-SSW trending in granitic ride. The greenstone belt located in Houndé southwest of Burkina Faso is the subject of this study. Previous works have specified through geological mapping and metallogenic, geochemical and geophysical prospecting (Sattran \& al., 1984; Huot \& al., 1987; Milesi \& al., 1989; Bonkoungou 1994, Castaing \& al., 2003) lithological, lithostructural units, lithofacies and mineral resources. The company Orezone Inc., which owns several licenses in the area, had started exploration campaigns in the period 1998-1999 resulting in the discovery of several gold mineralized targets. A mineralized zone has raised work that pose the problem of lithostructural control of gold concentration. The core holes located in the Djarkadougou gold mineralization prospect clearly reinforce the means of investigation and recognition lithostructural context of the mineralization. 


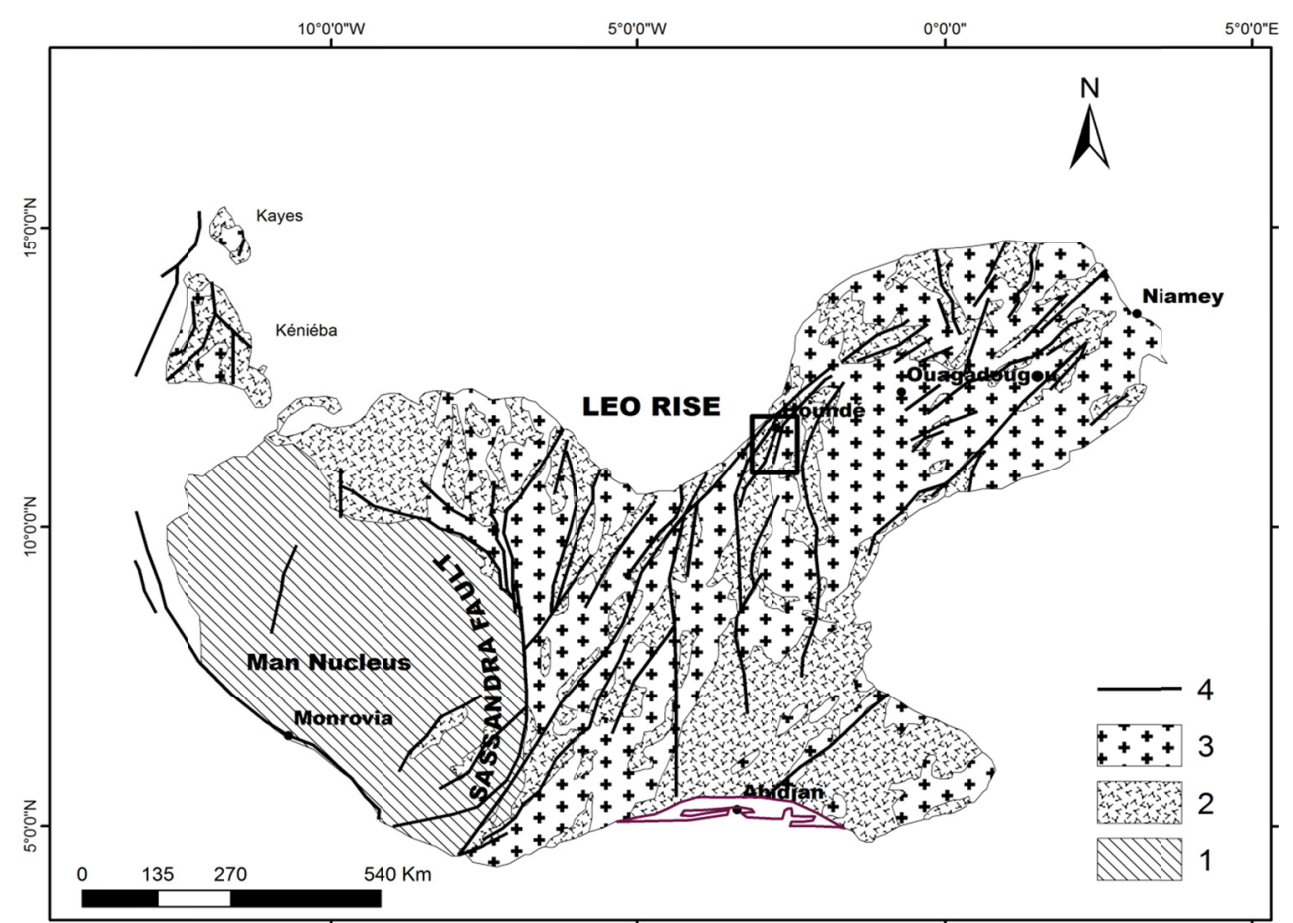

Figure 1. Simplified map of Leo shield (Milési \& al., 2004). 1: Archean basement, 2 volcano-sedimentary complex 3: Eburnean granitoid; 4: major faults.

\subsection{General Geological Setting}

The Baoule -Mossi paleoproterozoic domain consists of volcano-sedimentary rocks (Lemoine, 1988) which include significant mineral concentrations precious metals $(\mathrm{Au}, \mathrm{Pt})$ base $(\mathrm{Cu}, \mathrm{Zn}, \mathrm{Pb})$ and ferrous $(\mathrm{Fe}, \mathrm{Mn})$ economic interest for the countries of West Africa. These terranes, metamorphosed in the greenschist facies consist of sedimentary basins and narrow belts linear greenstone intruded by several generations of Eburnean granitoids. They correspond to an accretion period during orogenesis Eburnean around 2.0 Ga (Hirdes \& al., 1992; Taylor \& al., 1992). Lithostratigraphical succession of Birimian formations of the Baoule-Mossi domain long controversial (Vidal \& al., 1996), is now better specified in the different belts. It includes at the bottom: a thick sequence of basic rocks including tholeiitic basalts, dolerite and gabbro. These formations are interspersed by immature clastic sediments and carbonates. The clastic sedimentary pile made locally with dividers calc-alkaline volcanic rocks. At the top, a coarse clastic metasedimentary sequence attached to Tarkwaian system (Oberthür \& al., 1998) is interpreted as post-flysch Birimian deposits. From the structural point of view, several authors have recognized the polycyclic nature of the orogeny Eburnean (Bard, 1974; Vidal \& Guibert, 1992, Milési \& al, 1986 Ledru \& al., 1992.). They distinguish three major events of successive deformation: (i) the event (D1) tangential to the tectonic contact between Archean and Proterozoic formations; (ii) the event (D2) transcurrent associated with folds F2 of regional extension and a first generation thrusting NS to NE-SW trending often sinistral (Lemoine, 1988; Bassot \& Dommanget 1986; Ledru \& al. 1989; Liège \& al 1989). (Iii) The tectonic event (D3) is also transcurrent, described in Burkina Faso (Feybesse \& al., 1989). This event is marked by a folding accompanied by a foliation $\mathrm{S} 3$ oriented $\mathrm{N} 50^{\circ} \mathrm{E}$ to $\mathrm{N} 80^{\circ} \mathrm{E}$ (Ouedraogo \& Prost, 1986 ; Ouedraogo, 1987).

The prospect of Djarkadougou covers nearly $224 \mathrm{~km}^{2}$ in western edge of the belt Houndé. This belt follows the N-S or NNE-SSW trending and extends about $400 \mathrm{~km}$. The Djarkadougou permit is traversed by major shear zone Houndé-Ouahigouya of NNE-SSW trending. It includes a clastic unit Tarkwaian being squeezed to the east by volcanic formations composed mainly of andesitic flows and tuffs and felsic to mafic breccias, with volcano-sedimentary formations interbedded. The Bondigui microgranite intersects the volcanic rocks, like dykes felsic to mafic. Recent work (Ada \& al., 2011) have identified three phases of deformation. All rocks have been affected by various hydrothermal or weathering. 


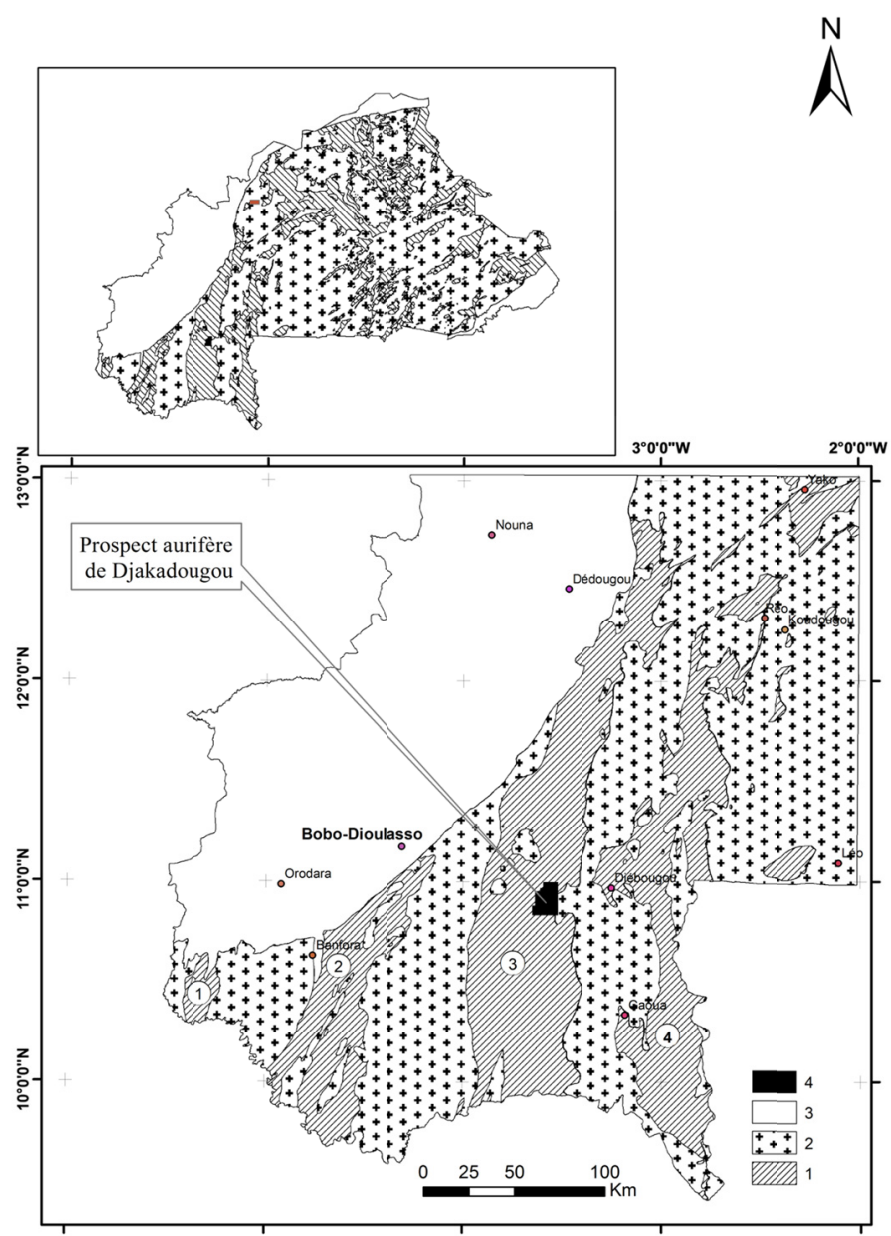

Figure 2. Location map of the Djarkadougou gold prospect in the southwest of Burkina Faso (West Africa). 1: volcano-sedimentary rocks (andesite tuffs, dacitic tuffs, ash tuffs and volcanic breccias); 2: biotite granites; 3: Major Faults and shear zones sinister movement 4: Djarkadougou gold prospect.

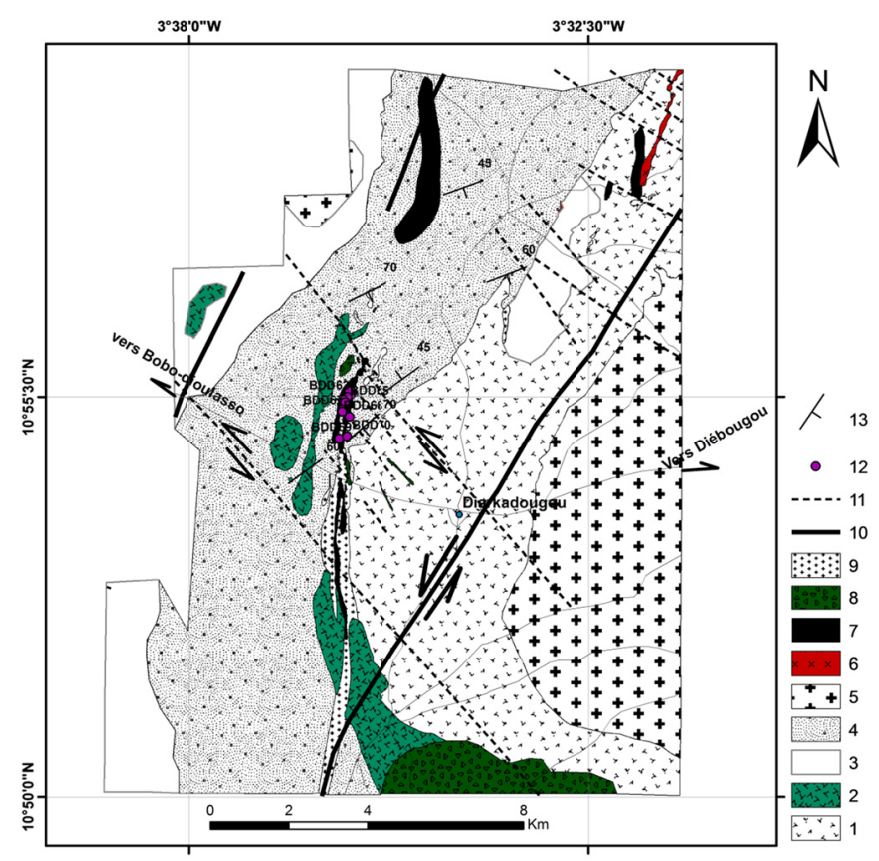

Figure 3. Geological of Djarkadougou gold prospect (according to the company Orezone Inc. 2008). 1: andesite-basalt flows 2: andesite flows; 3: Volcano-sedimentary rocks (tuffs, pyroclastic breccias); 4 : 
sedimentary rock type Tarkwaian; 5: Biotite granite; 6: porphyry rhyolite; 7: basic dykes (dolerite and gabbro-microgabbro); 8: intermediate dykes (diorite and porphyritic microdiorites); 9: granophyres

(quartz-feldspar dykes); 10: major fault; 11: minor faults; 12: core drilling point; 13: structures.

\section{Methodological Approach}

\subsection{Procedures Logging Surveys}

Ten (10) of DDH holes totaling 2,405.50 meters were drilled in the area studied by the company Orezone Inc. Almost all drilling points have a $50^{\circ}$ inclination to the South East except BDD66 tilted $60^{\circ}$ to drilling the North-west. The cutting of these cores according facies changes aimed at a lithological description and representative sampling. Sampling focused on the least altered rocks and different in nature covering the entire survey. This study present a lithostratigraphic column of the formations from Djarkadougou prospect (Figure. 4). One hundred thin sections of core samples realized to the Geology Laboratory of the University of Ouagadougou I Prof. Joseph Ki-Zerbo, were considered on the petrographic terms of Djarkadougou area. This macroscopic petrographic study was completed by microstructural analysis, and geochemical analysis.

\subsection{Geochemical Analysis}

Ten (10) rock samples were analyzed with ICP-MS on whole rock ACME Lab in Vancouver Canada. We proceeded to the multi-element analysis of representative samples of drill core, geochemical affinities to the petrochemical classification and geotectonic of volcanics Djarkadougou prospect.

\section{Results}

\subsection{Petrography}

The petrostructural study of prospect revealed three (03) major volcano-sedimentary units with alternating subordinated basic flows, andesitic dominant and common acids. The overall composition of volcaniclastic are acid like terrigenous sediments. The subvolcanic unit in vein form is dominated by dioritoïde injections incidentally by basic terms or acids. Metamorphic unit includes regional metamorphic rocks and contact. The gneiss, amphibolite and mylonite develop in the ductile shear corridors at breaking in with the nature of protholith (Figure 4). Finally, it appears from the study of Djarkadougou prospect (03) lithostructural three sets: they are volcanic and subvolcanic formations; sedimentary formations and plutonic formations of diorite variable composition, tonalite and granite. Identifying these rocks often tectonised and altered the area, required the petrological and mineralogical approach, based on recognition of primary minerals relics.

\subsubsection{Volcanic Flows}

The basalt flows, andesite, dacite and rhyolite, alternating with fine acids and projections are cut by the abyssal rocks.

\subsubsection{Basalt and andesite flows}

They recognize themselves in this area by a color dark green to greenish gray (Figure.5.b). They are usually sheared and schistosed but aphyric texture porphyry is locally preserved.

In the basalt flows, the microporphyric texture appears frequently. The groundmass of the rock is composed of plagioclase microlite and pyroxene more or less ouralitized rich and dense granules. In scattered state, are relatively fresh pyroxene as microphenocrysts.

The andesite flows are an important sequence in all core holes. Their texture is variable which distinguishes several facies: (i) very dominant spherulitic andesite: they are composed of plagioclase and hornblende spherulite to bluish ouralitic are in the state of relics; (ii) porphyritic amygdalar andesite: they show a matrix formed of plagioclase microlites of felting more or less destabilized encompassing plagioclase phenocrysts saussuritized. Amygdals are filled with hydrothermal minerals (quartz, carbonate \pm chlorite epidote). 


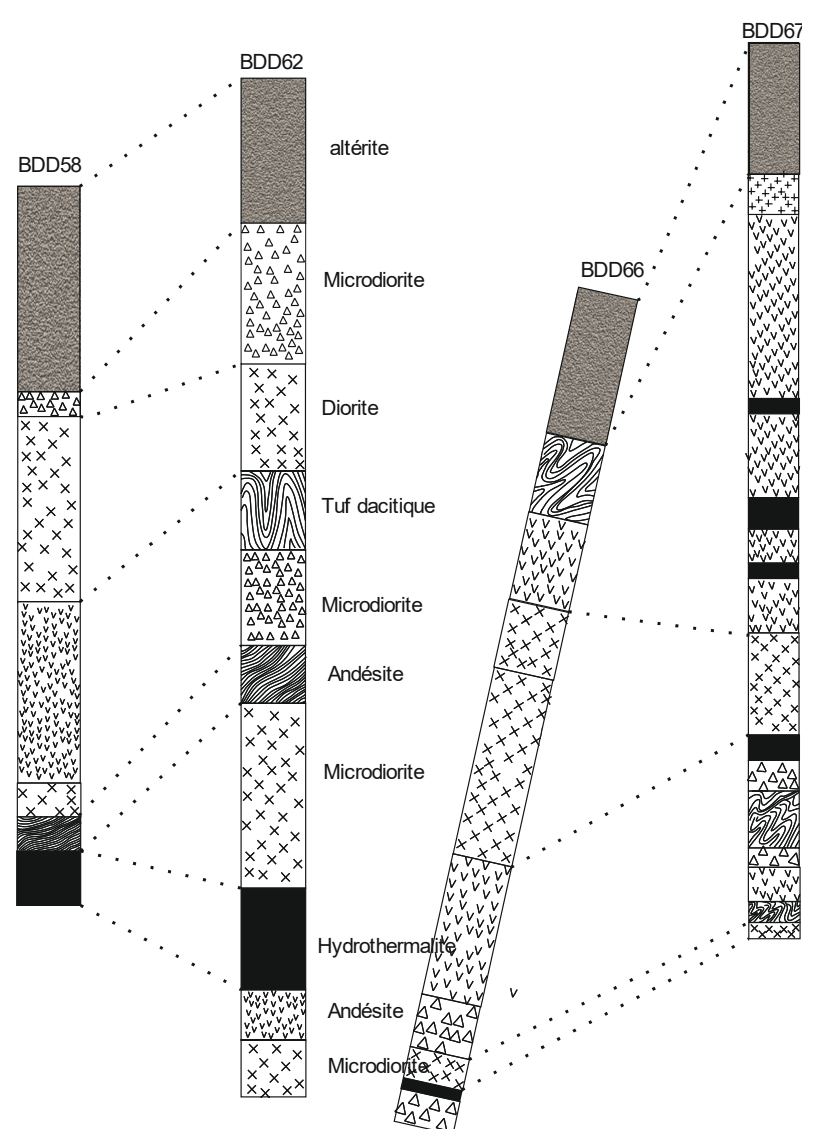

Figure 4. Stratigraphic column established from the study of core samples from Djarkadougou prospect
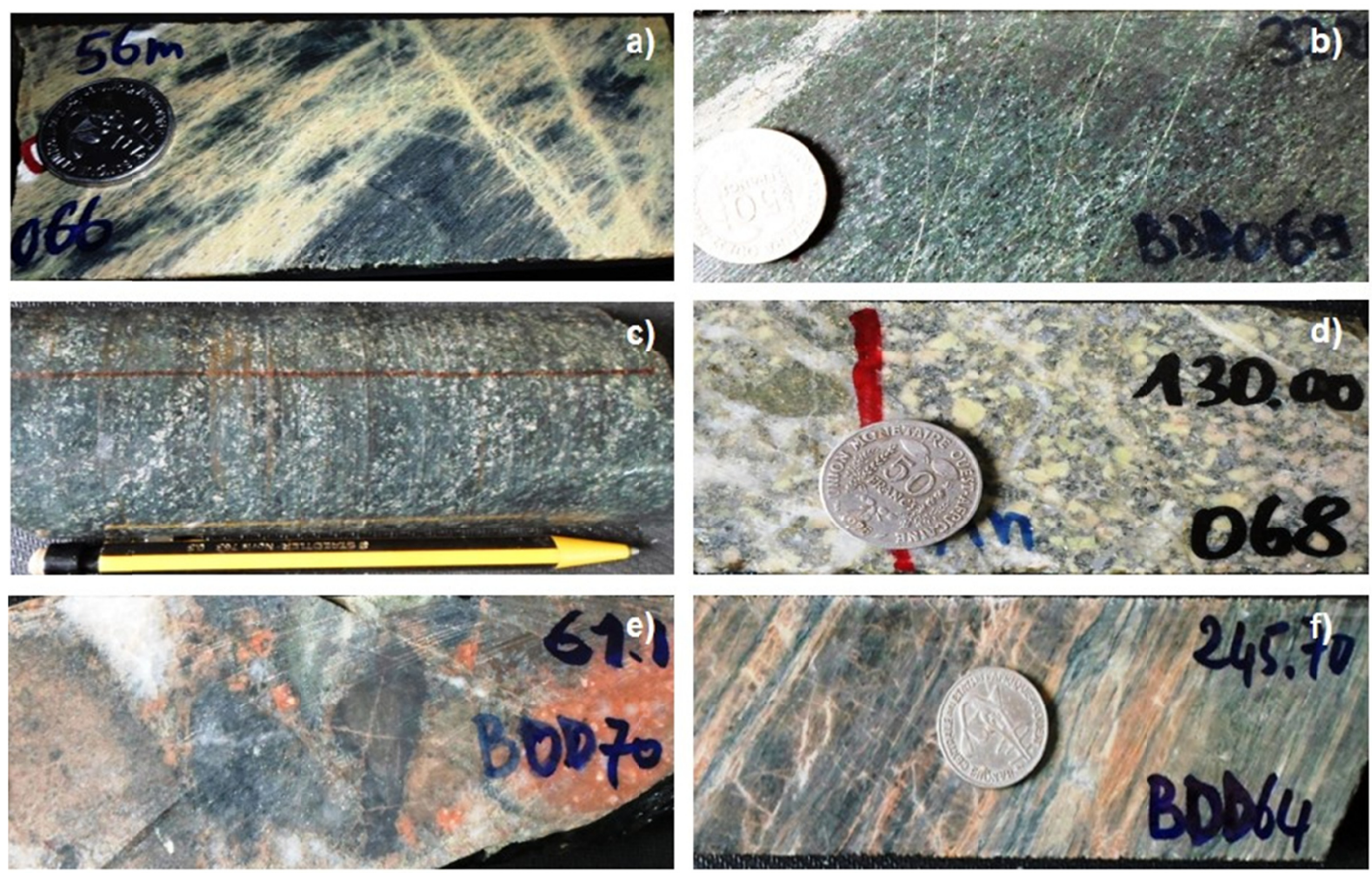

Figure 5. Macroscopic description of some typical rocks of core drilling Djarkadougou. (a): spherulitic rhyolite to 56 meters deep in BDD066 drill core with cracks filled with albite and epidote, (b) Andesite porphyry spherulitic to 36 meters deep in BDD069, c): microdiorite porphyry speckled with plagioclase; (d): sheared 
tonalite to coarse crystals automorphe greenish plagioclase (depth of 130 meters in BDD068); (e): microconglomerate polygenic with pebbles of diorite, quartz and black chert 61.50 meters in BDD070; (f): orthoschist banded with strips of sericite and chlorite to 245.15 meters in BDD064

\subsubsection{Dacite and Rhyolite Lava}

The acid rock flows were observed in drilling BDD064 and BDD066, plurimetric thickness intercalated in basic flows. Contact, when observed with andesitic rocks is clean. The fracture is conchoidal and splintery with a more or less glassy.

The dacite flows have varying textures, spherulitic porphyritic to glomeroporphyritic (Figure. 6.c). The groundmass consists of combining spherulites chopsticks plagioclase ghostly centered on a nucleus biotite. It includes plagioclase porphyritic sometimes in clusters, actinolite, biotite and muscovite destabilized into opaque and a small amount of igneous quartz.

Spherulitic porphyry texture also observed in rhyolitic lavas. The groundmass consists of spherulites of plagioclase, orthoclase and quartz. Ferromagnesian probably biotite are decomposed into muscovite, chlorite and opaque.
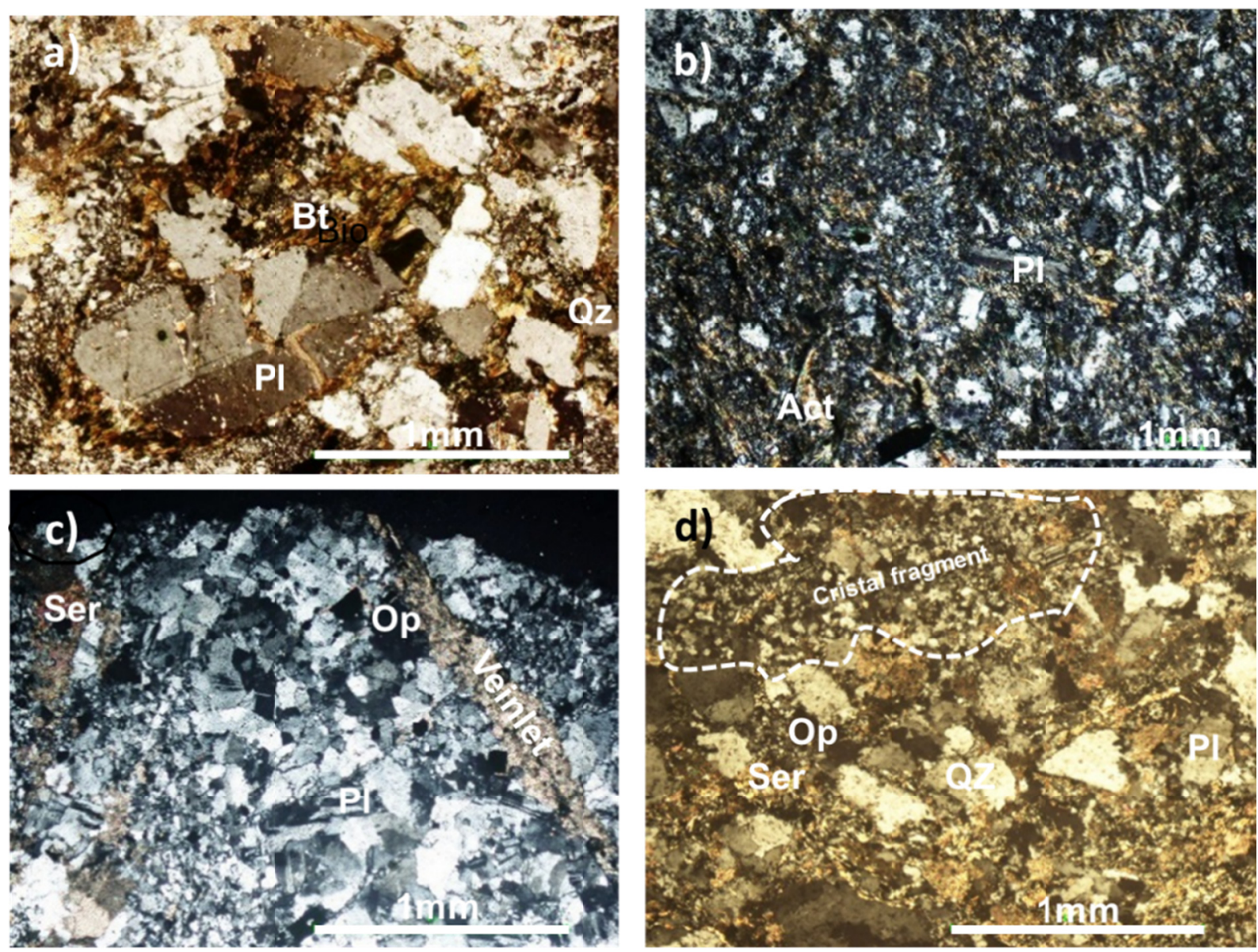

Figure 6. Micropetrographic character of volcanic rock taken from the gold prospect Djarkadougou. (a): (D66 P2) rhyolite; (b): Andesite spherulitic (D64 P7); (c): D64P13 dacite spherulitic veinlets filled with carbonate; (d): rhyolitic tuffs (D64P20).

\subsubsection{Volcanoclastites and Volcano-Sedimentary}

Mineral composition and size of mineral fragments equate with felsic tuffs in heterogranular texture.

The dacitic lithic and crystal elements tuff. They share the same mineralogical composition marked by abundant 
fragments of plagioclase and small amount of orthoclase, microcline and quartz. Biotite relics is replaced by muscovite and opaque. The scarce lithic fragments are felsic cinérite composition. The crystal rhyolitic tuffs have a composition controlled by the abundance of angular quartz crystals rolling and by fragments of plagioclase and orthoclase micropegmatite and with less abundant biotite lamellae.

The graphite epiclastites: they are layered and inserted into the tufaceous deposits. The intersection $\mathrm{S}_{0}$ and $\mathrm{S}_{1}$ related to the shear causes a cleavage of intersection lineation emphasized by iron oxides.

\subsubsection{Hypabyssal Rocks}

The subvolcanic rocks literally intersect volcanic and plutonic sequences. Some of them form veins, by against other could correspond to solidified contacts. Their composition is variable but remains dominated by neutral and intermediate terms. These are microdiorites, dolerite and granophyres.

The microdiorites: they are strongly represented in the core drilling BDD64, BDD68 and BDD69 (Figure 5.c) with a thickness ranging from $50 \mathrm{~cm}$ to $3 \mathrm{~m}$. These rocks are often sheared, mylonitized or ultramylonitized with asymmetrical microfolds, and also affected by hydrothermal alteration. Texture and residual mineral composition allowed to distinguish several facies: (i) biotite quartz microdiorite porphyritic (D69P8) with a shear structure underlined by a fine recrystallization felsic minerals; It sometimes presents many grinding zones traversed by late cracks filled with quartz, chlorite clusters associated with opaque; (ii) amphibole porphyry microdiorite consists of microcrystals and coarse damouritized plagioclase zoned crystals.

It shows a sheared structure whose planes $\mathrm{S} / \mathrm{C}$ are underlined by a fine granoblastic recrystallization and hydrothermal minerals (chlorite, carbonate) and relics of bluish green hornblende and opaque synkinematic stretched; (iii) porphyry intergranular microdiorite is determined abundance of feldspars $(0.5-1 \mathrm{~mm})$ under some form of phenocrysts with quartz in small quantities.

The dolerites: they show a coarse spherulitic texture marked by a provision spherulite wreath made of long strips of plagioclase and bluish green hornblende. Dolerites porphyry consist essentially of plagioclase and ouralitized pyroxene and accessory olivine crystals.

The granophyres: they are observed in the drills generally in association with microdiorites which form small veins of $10 \mathrm{~cm}$ to $30 \mathrm{~cm}$ of thickness. The rock is grayish tint, fine grained to porphyritic. We distinguish microscopically that granophyric porphyritic texture is typical of this rock. The original rock is made of an aggregate of symplectic and spherulitic plagioclase and orthoclase, microcrystals of plagioclase and biotite relic. The quartz phenocrysts with deformation bands, plagioclase and orthoclase are scattered throughout this groudmass. The granophyres could match either of vein rocks or solidified contacts between granitoids and volcanic rocks.

\subsubsection{Sedimentary Formations}

Detrital sediments are summarized with polygenic conglomerate, facies feldspathic sandstone to coarse-grained way to end frequent widely expressed in the survey BDD070 (Figure.5.e). Heterogranular clastic rocks, are made of angular quartz debris abundant fine to coarse, predominant plagioclase on orthoclase. Muscovite and opaque are the biotite destabilizing products. The damouritization of plagioclase is systematic in all facies. The often angular appearance of lithic elements and minerals debris shows little change in character of the transport.

\subsubsection{Plutonic Rocks}

In Djarkadougou prospect plutonic rocks are divided into:

Diorites: they appear at a depth of about 50 meters in the survey BDD058 and BDD059. They have a grainy texture varying from under medium grain gray light gray greenish minerals. Hornblende quartz diorite sometimes has a grainy heterogranular texture. Overall, the sheared facies and mylonitized undergo hydrothermal alteration propylitic kind (chlorite, epidote and carbonate). Some less processed facies show tabular crystals euhedral to anhedral, sometimes syneusitic association of zoned plagioclase crystals from side sub-euhedral to anhedral green hornblende. Rolling quartz and opaque igneous have an interstitial character.

Gabbros, being composed of quartz gabbro and pegmatitic gabbro. Like diorites, they are affected by the same hydrothermal alteration of propylitic type. The long strips of hornblende and plagioclase are finely recrystallized.

Granitoids: this group comprises biotite leucocratic granites. In the survey BDD61 appear, light green to gray pinckish granites in a brecciated structure. Before brecciation, rock recorded a mylonitic ductile deformation. The fragments are separated by areas of grindings marked by felsic minerals fragmentation and hydrothermal recrystallization of carbonates, muscovite and chlorite. The figurative elements of granite have a granoblastic texture expressed by sub jagged grains crystals of quartz and feldspar (orthoclase, plagioclase). 
The tonalite: these rocks are distinguished in the sampling frame with only biotite or biotite and amphibole facies. They met in the shear corridors of ductile deformation or brittle show variable degrees of processing going on to cataclastite, eyed mylonite and blastomylonite described in a specific chapter. These rocks are hydrothermally altered into carbonate and chlorite. In cataclastic and little altered facies, minerals relics are essentially coarse plagioclase, quartz and interstitial poecilitic scarce to rare orthoclase. The syneusitics plagioclase association and mafic digestion microtextures by late felsic minerals have locally preserved.

\subsubsection{Metamorphic Rocks}

\subsubsection{The Regional Metamorphic Rocks}

These rocks have been recorded within the shear corridor of the Djarkadougou gold prospect. They correspond to the formations affected by tectono-metamorphic phenomena and more or less by hydrothermal alteration where primary minerals have been partly or totally replaced by crystals of carbonates, chlorite and damourite. These are orthoschist (Figure.5.f) amphiboloschist, the gneissic and mylonite formations.

The orthoschists: they are derived from crystals felsic tuffs in shear zones recording the S1 cleavage refolded by P2 folds. Porphyroclastic eyed microtexture is defined by the presence of numerous quartz-feldspar almonds.

The amphiboloschists: they are expressed in the drills BDD60 and BDD62, with a green-light color characteristic. They are orthoderived from basic rocks widely recognized in the shear zones and are characterized by a clean schistosity (Figure.6.b). The mineralogical composition consists of a felting needle actinolite and hornblende more or less bluish reminiscent actinolite amphibolite facies at low degree epidote. The granonematoblastic microtexture is characteristic to this variety of amphibolite.

Gneissic formations: their origin is diverse and controlled by the nature of the protolith (granitoid, basic rocks) and the degree of mylonite formation in particular. Mylonite foliation characteristic of these formations is marked by alternating felsic microcrystalline or cryptocrystalline ribbons. The eyed texture or grano-porphyroclastic appears in the felsic gneiss facies. The nematoblastic or grano-nematoblastic texture is for classical amphibolitic terms. The main types of rocks gneissic in the prospect are: orthogneiss tonalitic, orthogness dacitic and eyed orthogneiss mylonitic. This facies to banded structure is leucocratic in small bands of andesite. The alternating felsic microcrystalline ribbon and tape mica biotite relics of muscovite and opaque is related to the mylonite foliation will remain despite recrystallization relics small almond plagioclase and angular quartz that remind an old pyroclastite felsic.

Biotite leptynic gneiss: to the naked eye, they are also leucocratic rocks oriented structure with a brecciated texture. Microscopically the rock corresponds to biotite gneiss structure by alternating felsic cryptocrystalline strip and mica bands (old biotite destabilized into muscovite opaque \pm ). Note that the felsic bands are hydrothermally with significant changes in carbonate, muscovite and opaque granules.

Eyed biotite leptynites are characterized by thinly foliated structure marked by a felsic and micaceous (chlorite, muscovite) banding. Feldspar eyes are embedded in a matrix of heterogranulars (plagioclase, orthoclase) felsic blast aggregate.

The amphibologneiss in several drills associated with microdiorites and porphyry naked eye andesite or with hydrothermally altered rocks. The rock presents a foliated structure and there show a banded structure and grano-nematoblastic eyed texture (Figure 7.a). The ribbons are plagioclase finely recrystallized sometimes damouritized or destabilized and epidote and elongated amphibole crystals ribbons, frayed finely recrystallized and associated with opaque crystals very stretched, and sometimes microfolded and destabilized in leucoxene. Sphene, damouritized plagioclase and bluish green hornblende form small sigmoid almonds molded by the foliation. The quartz is scarce and rolling show extinction. Late cracks filled with carbonates or chlorite while the crushed zones are enriched in epidote.

\subsubsection{Contact Metamorphic Rocks}

Surveys are usually positioned near the plutonic formations particularly, tonalites. Hornfels are recognized by their granoblastic poeciloblastic or polygonal microtexture and by abundant opaque granules in the rock. They come from the thermal contact induced by hololeucocratic biotite granite and tonalite. Facies (Fig.7.d and c) with biotite isograde recrystallized hornfelsed mainly formed at the expense of the expense of microdiorites or spherulitic dacite biotite quartzite result of processing by contact feldspathic sandstone. 

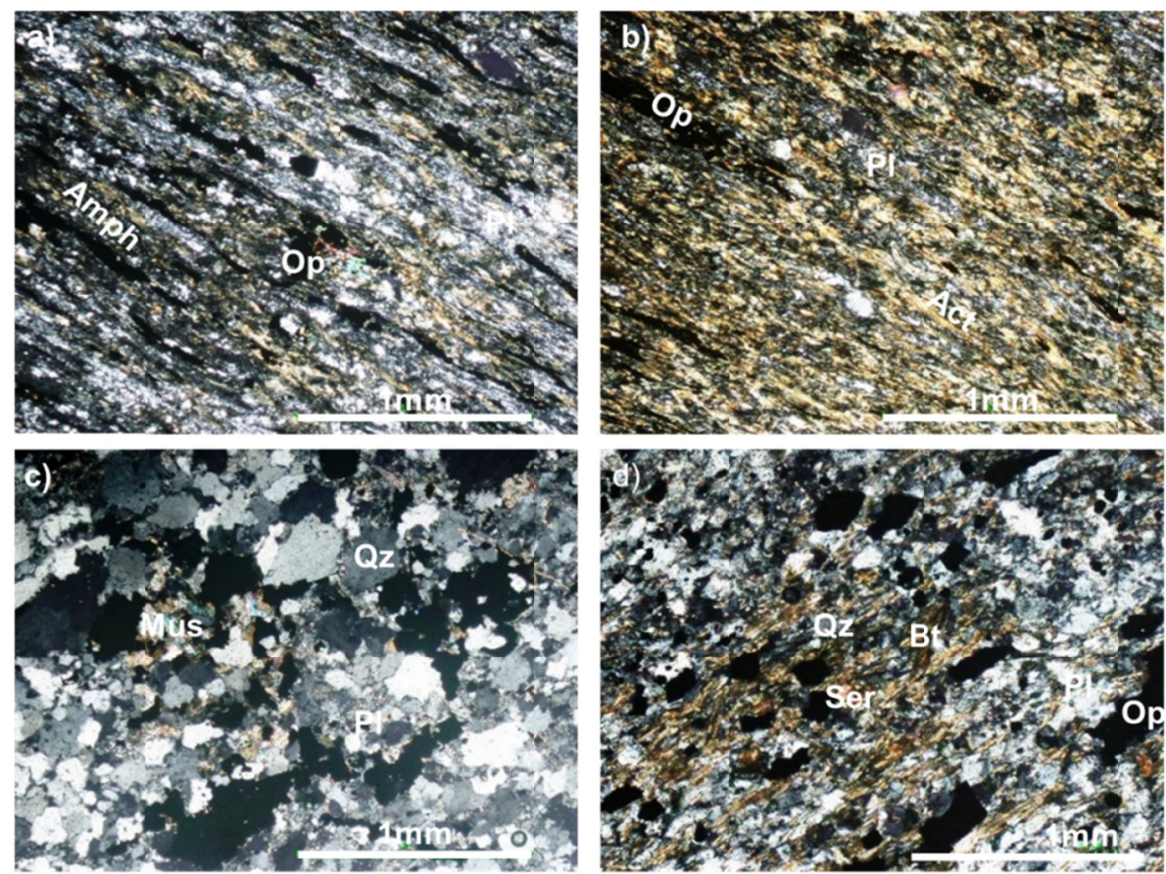

Figure 7. photography of metamorphic rocks and feldspathic sandstone. (a): amphibologneiss; (b): actinotite; (c): sandstones; (d): biotite hornfel

\subsubsection{Mylonite Rocks}

They are sheared and fractured. We distinguish cataclasites and mylonites depending on the presence or not of the primary cohesion and foliation. The cataclasites are produced by the brittle deformation with a mechanical disintegration of the rock accompanied by the reduction of the grain size during the deformation. The fragments derived from cataclasic rocks are significantly coarser well within the recrystallized and slightly sparse matrix.

The term mylonite was proposed by Lapworth (1885) which means broken rock, here the term is associated with ductile-brittle deformation. Several authors have attempted to define the textural variations in rocks located in the shear zones and fault zones. Following the work of Spry (1969) and Sibson (1977) suggested a more precise classification of mylonite Tab1. But to be more objective, Wise et al. (1984) attempted to define the mylonite based on two variables, the rate of deformation and the recovery rate as the rate at which the rock crystallized readjusts. Criticism of Mawer (1986) about the use of mylonite their use to a subjective connotation. He recommends always to describe what they referred. Thus, Mawer (1986) defines mylonite as rocks which occupy a shear zone through which a block has been moved relative to each other.

They are well foliated, layered and generally show a reduction of the grain in comparison with the rock. Fabric $\mathrm{C} / \mathrm{S}$ rotations porphyroblasts and other textures are common therein.

Table 1. Classification of rocks mylonite (Sibson, 1977)

\begin{tabular}{|c|c|c|c|c|c|c|}
\hline \multirow{6}{*}{$\begin{array}{c}\text { With } \\
\text { cohésion }\end{array}$} & $\begin{array}{l}\text { Glassy } \\
\text { groundmass }\end{array}$ & pseudotachylite & & & & \\
\hline & \multirow{4}{*}{$\begin{array}{l}\text { The matrix } \\
\text { character }\end{array}$} & \multicolumn{3}{|c|}{$\begin{array}{l}\text { Breccia to coarse grain (fragments }>0.5 \mathrm{~cm} \\
\text { Breccia to medium grain }(0.1<\text { fragments }<0.5 \mathrm{~cm} \text { ) } \\
\text { Microbreccia (fragments }<0.1 \mathrm{~cm} \text { ) }\end{array}$} & $0-10 \%$ & \multirow{4}{*}{$\begin{array}{l}\text { Proportion of } \\
\text { the matrix }\end{array}$} \\
\hline & & protocataclasite & \multicolumn{2}{|c|}{ Protomylonite } & $10-50 \% \%$ & \\
\hline & & Cataclasite & \multirow{2}{*}{ Phyllonite } & Mylonite & $50-90 \%$ & \\
\hline & & Ultracataclasite & & Ultramylonite & $90-100 \% \%$ & \\
\hline & $\begin{array}{l}\text { Increase of grain } \\
\text { prononced }\end{array}$ & & \multicolumn{2}{|c|}{ blastomylonite } & & \\
\hline
\end{tabular}

We distinguish, based on microscopic observations:

Protomylonite: the matrix has a mylonitic foliation with very low proportions of microcrystals occupying 10 to 
$50 \%$ of the rock. The rock is taken in cores of BDD68 survey. It is slightly altered and sheared. The protomylonitic texture is clearly seen in granophyric and tonalite rocks. In the microscope, the rock has a protomylonitic texture with fine plagioclase clasts dominant. It is composed of plagioclase and orthoclase accessory storing relics of microcrystals and plagioclase phenocrysts sometimes zoned often recrystallized, with associations granophyric and spherulite plagioclase and orthoclase relicts quartz phenocrysts showing deformation bands.

Mylonite: It appears in the BDD68 survey related to deformation and recrystallization porphyry microdiorites. The green-greyish rock is foliated and sheared with a labeled plastic deformation. The proportion of large crystals occupy $10-50 \%$ of the rock. This character is clearly visible around the contact between plutons and volcanic and volcano-sedimentary rocks. Microscopically, it has a stage of plastic deformation and brecciation phase. The first comprises finely ghostly recrystallized coarse microcrystals (Figure 8.b), the second is related to an intense network of cracks and fractures and grinding strike slip zones insulation small rock fragments mylonitic.

Ultramylonite: The nature of the rocks most recognizable (Fig 8.c). The mylonitic texture results in abundant plagioclase replaced by a static recrystallization but retaining the forms in long strips. The green hornblende amphibole types initially in the form of long sticks is broken and finely crystallized. Chloritization of important microblasts amphibole with opaque exudation, plagioclase processing in clusters of epidote and carbonate, damourite accompany mylonitic deformation. The presence of mineral relicts wand reflects a subvolcanic origin of the protolith.

Blastomylonite: they are not defined in terms of fragments as the preceding, however in these types of rocks abundant recrystallization is observed, accompanied by a mineral growth and a ribbon structure. Representative samples exist in BDD70 and BDD68 drills. At the microscopic scale (Figure 8.d) indicates that the matrix is formed of small blasts relics of plagioclase and orthoclase dominant accessory, racing to porphyroblasts abundant plagioclase, orthoclase and little abundant quartz in a matrix of carbonate and mica (sericite, muscovite, chlorite) and relatively abundant granules in the form of streaks. Quartz phenoclasts exhibit deformation bands while those of plagioclase are broken and show frequent mechanical twinning and phenomena perthitization.
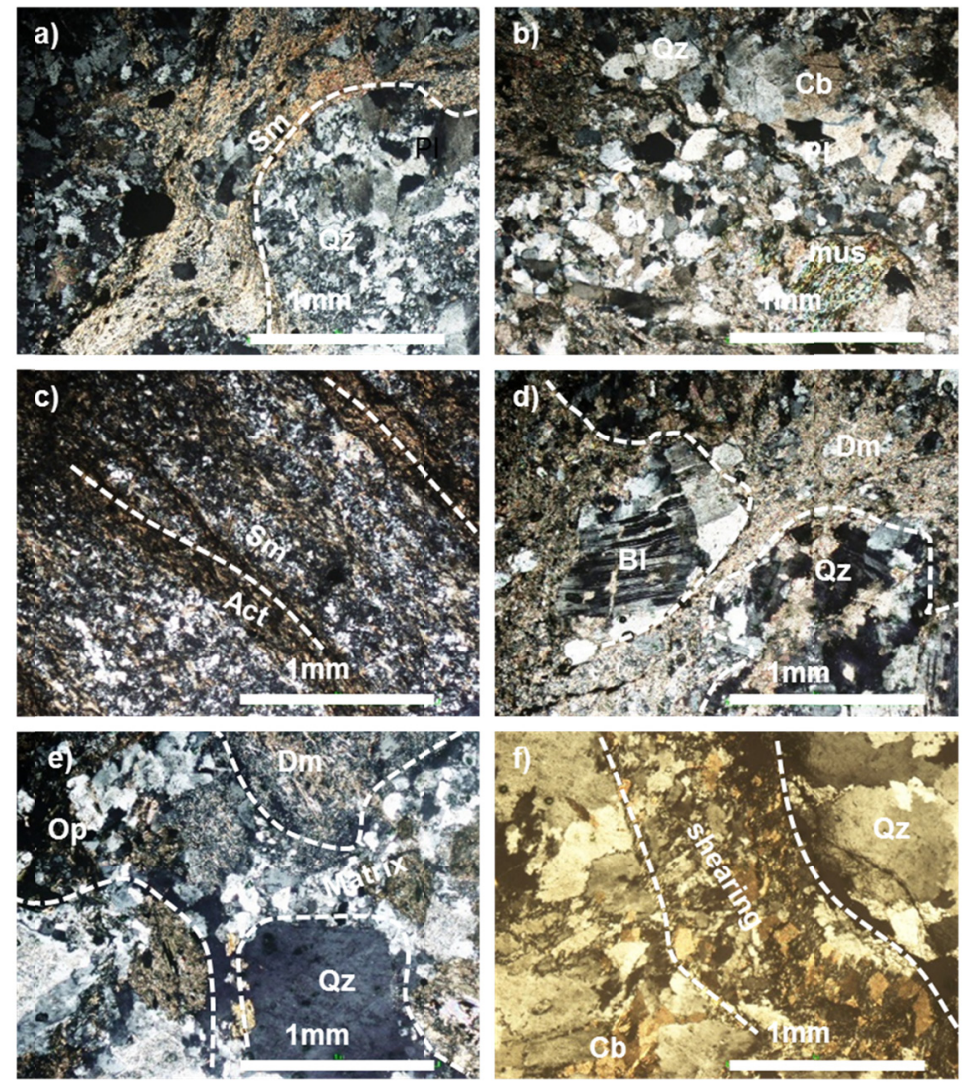

Qz: quartz; Cb: carbonate; Dm: Damourite; Act : actinolite ; Op : opaque ; mus : muscovite ; Bl : blastoid ; Sm mylonitic cleavage

Figure 8. microphotography showing the different intensities of deformations in the heart of the shear zone. (a): 
D68P12 Biotite and amphibole tonalite affected by many breaks accompanied by recrystallization granoblastic felsic and hydrothermal minerals with a protomylonitique texture.( b): D68P8 tonalite texture mylonitic.(c): D69 P13 an ultamylonitized hydrothermally altered microdiorite. (d): D68P7 blastomylonitic texture with quartz phenoclast exhibit deformation bands while those of plagioclase are broken and show frequent mechanical twinning and phenomena of perthitization from original tonalite. (e): D68 P10 Rock affected by numerous cracks filled with hydrothermal products. (f): D61P14 biotite leucocratic Metagranite brecciated presenting the breach of elements separated by zones of grinding marked by felsic minerals fragmentation and hydrothermal recrystallization.

\subsection{Structural Analysis}

\subsubsection{Brittle-Ductile Deformation}

It characterizes the shear zones or distortion expressed with varying intensity but not progressive. In these areas, the microstructures recorded by core drilling in lithofacies correspond to shear-zones marked by cleavages S1 / S2, asymmetrical and symmetrical folds, stretching lineations. Schistosity S1 is regularly observed in volcanic and volcano-sedimentary rocks assigned to a first tectonic event of shortening. In this planar fabric is mainly defined by a preferential orientation of chlorite and amphibole (Figure.8.c and d).

Tectonites strongly sheared and schistosed are located in the central axis of the shear corridor where the schistosity S1 is locally recovery by fold F2. Tectonites are schistosed and foliated, generally mylonitized with a braided structure and primary structures disappear to make way for two families C and S (Berthe et al., 1979).

Structural studies have highlight asymmetrical folds and symmetrical folds. Asymmetric folds are combined to veins filled with calcite carbonates sometimes with quartz generally microboudined and usually sigmoidal showing sinistral shear. These structures affect mainly spherulitic andesitic rocks and rarely sedimentary rocks. The symmetrical folds are much rare but when they exist, their axial plane is subparallel to the shear foliation.

Schistosity S2 corresponds to a cleavage crenulation and is irregularly developed in tectonites. This secondary structure is expressed by microfolds or kink-bands taking the S1 cleavage. Schistosity S2 corresponds in fact to parallel microfolds tight isoclinal to subvertical axial planes. This cleavage corresponds to a ductile deformation phase less intense than that at the origin of the main foliation. The volcano-sedimentary stratification S0 keep cores in the form of alternating centimetric to metric benches. S0 stratification is sometimes confused with S1 and S2 cut by the cleavage, develops intersection lineations in epiclastites. These structures are less obvious in terrigenous sediments.

\subsubsection{Brittle Deformation}

It succeeds the ductile shear deformation mylonite with a first stage cataclastic related to tectonic brecciation and accompanied by grinding lithofacies sheared mylonitic to ultramylonitic and associated gneissic formations. The magmatic brecciation or hydraulic fluid under pressure could be synchronous tectonics coming. Microscopic examination shows the polyphasis fissures microtectonic of which two (02) to $F_{n}$ several steps, the last $F_{n+1}$ is transcurrent of all polydeformed rocks.

The chlorite and carbonate alteration of varying intensity is also polyphasis and is accompanied by brittle deformation affecting intermediate and basic magmatism dominant late fissure sealing overlaps locally or comprehensiveness of the rocks through the stringer microdiorites or dolerite.

The brittle deformation intensely used by fluids led to metasomatic transformations protoliths and the hydrothermal-rock training hydrothermal alteration affects metamorphic contact and regional rocks and implies a continuous process and late.

\subsubsection{Veins and Veinlets}

In hydrothermal deposits in the world characterization of the veins and vein systems was made on the basis of textural and structural styles. In Djarkadougou the prospect study, we distinguish between three (3) types of veins from the work of Sibson (1990):

Veins and veinlets filled with chlorite-carbonate and quartz-carbonate generally NNE-SSW trending. These veins and veinlets parallel to the foliation (S1). They are sometimes boudined and localized in small asymmetrical folds.

Shear veins strongly sheared and laminated locally boudined. These veins are filled quartz-sulfide-carbonate and localized to the heart of the shear zone. These veins are formed under local compression conditions and high 
differential stress. These conditions are developed during the D2 phase.

Veins and veinlets which intersect obliquely to the regional NNE foliation, are oriented NE-SW, NW-SE and are variable dips. These late veins are usually filled with sphalerite, pyrite, calcite and quartz.

\subsection{The Metamorphism}

Petrographic study showed that the rocks have undergone several episodes including regional or contact metamorphism with secondary hydrothermal transformations. Regional metamorphism is registered under greenschist facies conditions by volcanic, subvolcanic and plutonic basic and intermediate formations. The paragenetic features are albite, actinolite, chlorite and epidote characteristic of greenschist facies. In all rocks of prospect, petrographic analysis allowed us to understand that the zone is affected by hydrothermal metamorphism. It follows from the fluid action correlated with the brittle or ductile deformation. Hydrothermal phases define hydrothermal mineral assemblages very low temperature which carbonates, chlorite, damourite, epidote are common species.

\subsection{Geochemistry}

\subsubsection{Major Geochemical Characters}

Analysis of major and traces elements (Table 1) and representation in the diagram of Winchester and Floyd 1977 $\mathrm{Nb} / \mathrm{Y}$ versus $\mathrm{Zr} / \mathrm{TiO} 2$ volcanics of Djarkadougou prospect indicate compositions of basalts, andesi-basalts, andesites and rhyolites. Basalts are characterized by $\mathrm{SiO} 2$ content varying from $48.14 \%$ to $50.64 \%$, of alkali ( $\mathrm{Na} 2 \mathrm{O}+\mathrm{K} 2 \mathrm{O}$ ) $2.71 \%$ to $4.13 \% \mathrm{Al} 2 \mathrm{O} 313.02 \%$ to $14.33 \%$ and $\mathrm{TiO} 2$ (1.45 to $2.78 \%$ ). The $\mathrm{MgO}$ values are $3.61 \%$ to $6.55 \%$. Andesites are characterized by $\mathrm{SiO} 2$ content between 50.64 to $58.28 \%$, alkali (Na2O $+\mathrm{K} 2 \mathrm{O}) 2.71$ to $6.21 \%$ ), 2.82 to $4 \% \mathrm{MgO}$, and low values $\mathrm{TiO} 2$ : 0.73 to $1.91 \%$.

The rhyolites are distinguished from basic and intermediate volcanics by their high silica component. These volcanic rocks are subalkaline composition in Winchester and Floyd diagram, 1977 (Figure 9.a)
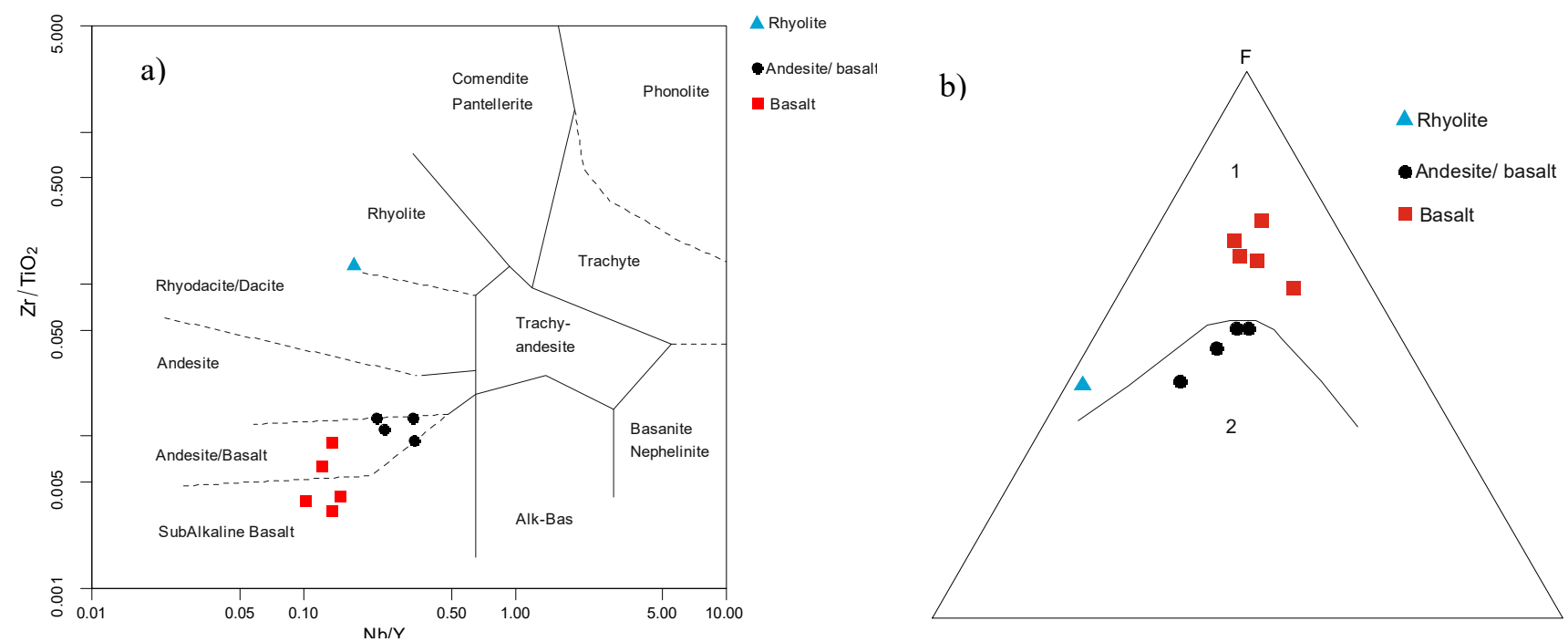

Figure 9. a): Diagram of classification of Winchester \& Floyd (1977) applied to the prospect of Djarkadougou volcanics. b): AFM diagram (Irvine \& Baragar, 1971) applied to Djarkadougou prospect volcanics with $\mathrm{F}=\mathrm{FeOt}$; $\mathrm{A}=\mathrm{Na} 2 \mathrm{O}+\mathrm{K} 2 \mathrm{O} ; \mathrm{M}=\mathrm{MgO} ; 1$ : tholeiitic field; 2 : calc-alkaline field

\subsubsection{Magmatic Affinities}

The AFM diagram (Figure 9.b) clearly discriminates two group, in one hand with calc-alkaline affinity, in the other hand with tholeiitic basalts and isolated rhyolites and by the characteristics of bimodal volcanism highlighted in the Perkoa, Bouroum and Gaoua regions (Napon 1988; Zonou, 1987 Wenmenga \& al. 2008).

\subsubsection{Traces Geochemical Characters}

Andesites have average vanadium contents between 155 and $183 \mathrm{ppm}$. Contents of rubidium, cobalt and nickel are low and respectively from 1 to $33.2 \mathrm{ppm}, 19.61$ to $33 \mathrm{ppm}$; less than 20 to $58 \mathrm{ppm}$. Multi-elemental profiles of Taylor and McLennan (1985) show lithophile or incompatible elements Rb, Ba, Th, U, Ta, Nb, Hf depletion (Figure. 10) . This very marked $\mathrm{Tb}$ negative anomaly for andesi-basalts and andesites rocks is characteristic 
continental crust contribution; to the genesis of these rocks. The strong negative anomalies of Rb in basalts, andesi-basalts and andesites are induced by possibly biotite feldspar splitting in intermediate terms and for moderate and negative anomalies in all $\mathrm{K}$. Volcanic facies show low Ta, Nd negative anomalies, and very $\mathrm{P}$ and Ti positive, a little lower in Sr except rhyolites showing a different geochemical evolution with the opposite negative anomalies ( $\mathrm{P}, \mathrm{Ti}, \mathrm{Sr})$. Positive $\mathrm{Sr}$ anomalies involve a significant accumulation of plagioclase in the formation of basalts and andesites and especially andesi-basalts. Apatites and iron-titanes oxides are responsible, of Ti and P positive anomalies but geochemical behavior of these minerals are different in the rhyolites.

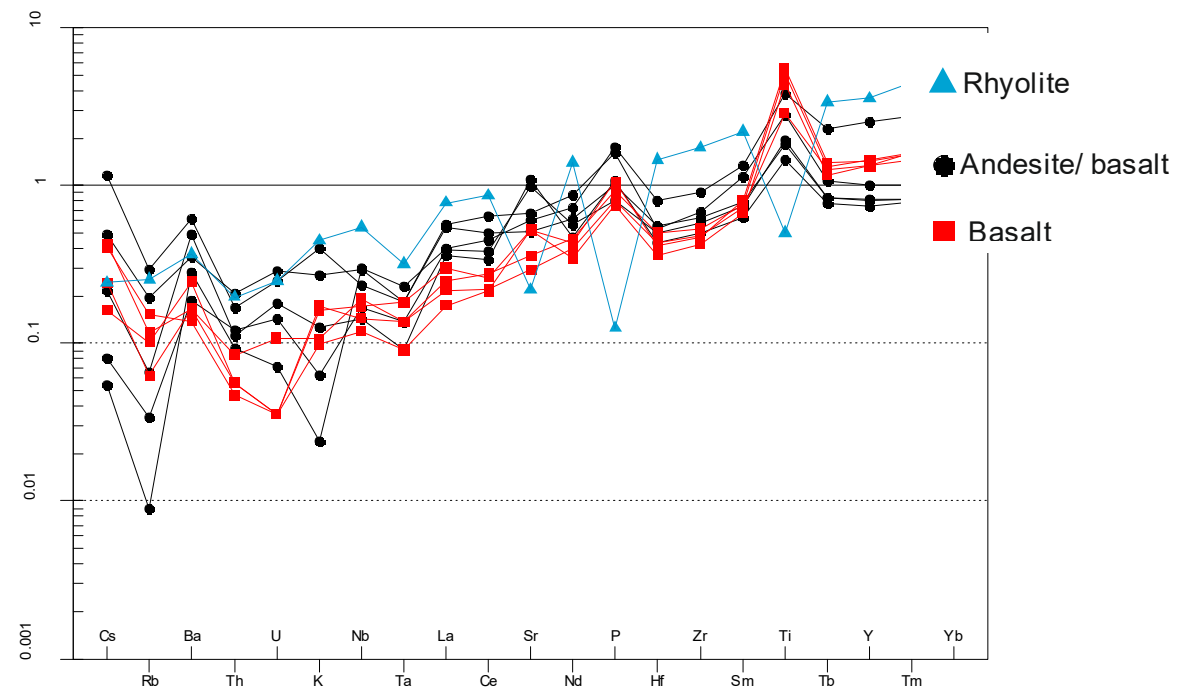

Figure 10. Multi-element diagram of andesite, basalts and rhyolite standardized to the upper continental crust (after Taylor \& McLennan 1985).

\subsubsection{Rare Earth Element}

Fractionation is marked by reports of couples $\mathrm{Rb} / \mathrm{Sr}$ very low (0 to 0.17$)$ and $\mathrm{Sm} / \mathrm{Nd}$ high $(0.22$ to 0.34$)$ compared to the respective values of 0.32 and 0.17 estimated (Taylor and McLennan, 1985) for the upper continental crust. The REE contents of basalts and andesites are reported on standardized chondrite (Boynton 1984; Figure.11).The andesite-basalts of the first group are distinguished from ordinary andesites by a different spectrum with Eu anomaly caused by a privileged crystallization of plagioclase. The parallelism of the spectra of andesi-basalt-like basalts suggest that these facies have cogenetic links. Andesites profiles are clearly discordant on the basalts spectra REE which confirm their differentiated composition and origin.

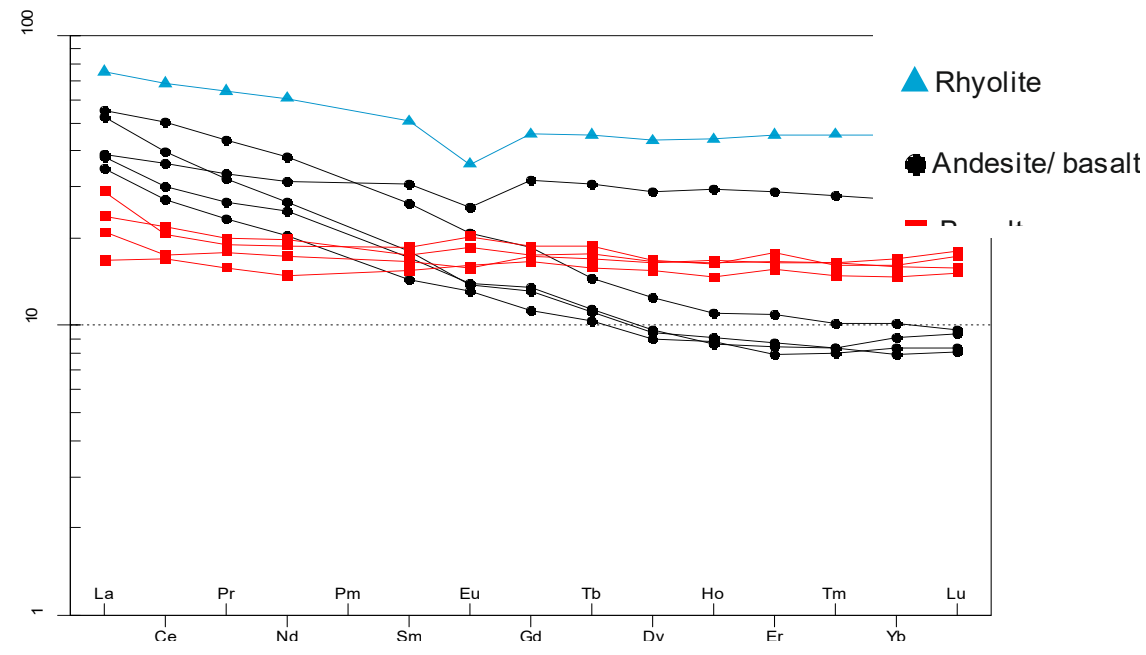

Figure 11. Rare-earth element spectra of basalts and andesite and rhyolite normalized to chondrite REE contents of basalts (Boynton 1984) 


\subsubsection{Geotectonic Setting of Djarkadougou Volcanites}

The chemical compositions of andesites and basalts are deferred on several discrimination diagrams. The diagrams $10 \mathrm{MnO}-\mathrm{TiO} 2-10 \mathrm{P} 2 \mathrm{O} 5$ indicate an affinity for MORB and $\mathrm{Zr} / 4-2 \mathrm{Nb}-\mathrm{Y}$ show membership in a geotectonic setting of overriding arc volcanism. Andesites are also marked by a ratio $\mathrm{Th} / \mathrm{Yb}$ high compared to basalts (Figure. 12) which suggests in this setting of intense subduction crustal contamination.

The diagrams $\mathrm{Nb} / \mathrm{Yb} \mathrm{TH} / \mathrm{Yb}$ and $\mathrm{Zr} / 4-2 \mathrm{Nb}-\mathrm{Y}$ confirm the affinity of Djarkadougou volcanites for intra-oceanic subduction zones allowed in the Birimian terranes related to Eburnean orogeny (Castaing \& al., 2003 ).
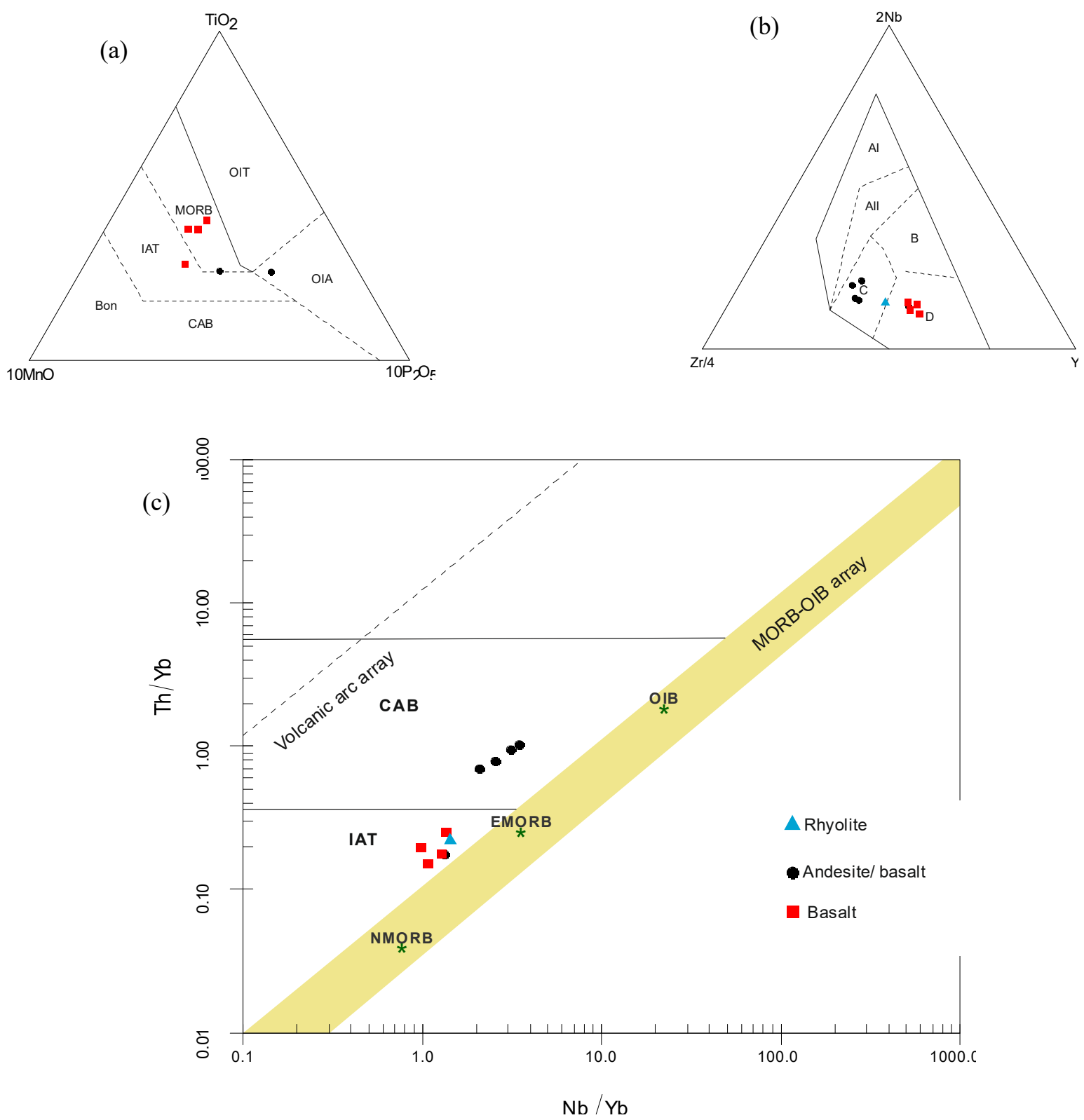

Figure 12. (a) Diagram 10MnO-TiO2-10P2O5 discriminating basalt andesite-basalts (Mullen, 1983). 1: tholeiitic field of oceanic arc; 2: MORB type basalts field; 3: tholeiitic island arc; 4: calc-alkaline basalt field type; 5: Field of alkalic basalts of the oceanic arc (b) discrimination diagrams $\mathrm{Zr} / \mathrm{Y}-4-2 \mathrm{Nb}$ (Meschede 1986) applied to basic and intermediate volcanic. AI: alkalic intra-plate basalt; IIA: intra-plate alkaline basalts and tholeiitic; B: E-MORB; C: tholeiite intra-plaque and volcanic arc basalts; D: N-MORB basalts and volcanic arc. (c) Diagram $\mathrm{Nb} / \mathrm{Yb}-\mathrm{Th} / \mathrm{Yb}$ applied to volcanites of Djarkadougou prospect illustrating enrichment of Th in the subduction zone or crustal contamination 
Table 2. Chemical analysis of major (\%) trace and rare earth elements (ppm) of volcanites of Djarkadougou prospect (South-west Burkina Faso)

\begin{tabular}{|c|c|c|c|c|c|c|c|c|c|c|}
\hline & D58P1 & D66P5 & $\mathrm{D} 62 \mathrm{P} 2$ & D68P16 & D58P8 & D60P3 & D60P9 & D64P5 & D64P6 & D66P2 \\
\hline $\mathrm{N}^{\circ}$ Ech. & \multicolumn{4}{|c|}{ Basaltes } & \multicolumn{5}{|c|}{ Andésites } & Rhyolite \\
\hline $\mathrm{SiO} 2$ & 50,64 & 48,28 & 48,14 & 48,54 & 48,26 & 58,28 & 54,4 & 57,13 & 53,94 & 76,46 \\
\hline $\mathrm{Al} 2 \mathrm{O} 3$ & 13,14 & 13,02 & 14,33 & 13,16 & 16,99 & 14,26 & 13,14 & 18,3 & 17,8 & 10,68 \\
\hline $\mathrm{Fe} 2 \mathrm{O} 3$ & 19,42 & 16,29 & 16,86 & 16,81 & 10,82 & 7,88 & 16,64 & 7,7 & 9,96 & 4,66 \\
\hline $\mathrm{MgO}$ & 3,84 & 6,55 & 4,34 & 3,61 & 4 & 2,93 & 2,88 & 2,82 & 4 & 0,25 \\
\hline $\mathrm{CaO}$ & 4,53 & 8,3 & 8,9 & 9 & 5,55 & 5,34 & 5,66 & 5,82 & 8,05 & 1,11 \\
\hline $\mathrm{Na} 2 \mathrm{O}$ & 2,35 & 2,43 & 3,3 & 3,59 & 3,74 & 2,97 & 3,75 & 5,78 & 3,71 & 3,89 \\
\hline $\mathrm{K} 2 \mathrm{O}$ & 0,36 & 0,58 & 0,33 & 0,54 & 0,91 & 1,35 & 0,08 & 0,43 & 0,21 & 1,51 \\
\hline $\mathrm{TiO} 2$ & 2,53 & 1,45 & 2,19 & 2,78 & 1,4 & 0,92 & 1,91 & 0,73 & 0,98 & 0,25 \\
\hline $\mathrm{P} 2 \mathrm{O} 5$ & 0,15 & 0,13 & 0,12 & 0,17 & 0,26 & 0,16 & 0,28 & 0,17 & 0,13 & 0,02 \\
\hline $\mathrm{MnO}$ & 0,19 & 0,22 & 0,21 & 0,25 & 0,12 & 0,86 & 0,24 & 0,12 & 0,13 & 0,11 \\
\hline $\mathrm{Cr} 2 \mathrm{O} 3$ & $<0.002$ & 0,026 & $<0.002$ & 0,005 & $<0.002$ & 0,008 & $<0.002$ & 0,007 & 0,013 & $<0.002$ \\
\hline LOI & 2,6 & 2,5 & 1,1 & 1,4 & 7,7 & 4,8 & 0,8 & 0,8 & 0,9 & 0,9 \\
\hline Sum & 99,8 & 99,76 & 99,77 & 99,83 & \multicolumn{4}{|c|}{ Traces elements } & 99,82 & 99,87 \\
\hline $\mathrm{Ni}$ & $<20$ & 134 & $<20$ & $<20$ & $<20$ & 57 & $<20$ & 26 & 58 & $<20$ \\
\hline $\mathrm{Sc}$ & 39 & 36 & 40 & 47 & 17 & 16 & 32 & 16 & 21 & 5 \\
\hline $\mathrm{Ba}$ & 91 & 76 & 90 & 135 & 194 & 335 & 155 & 269 & 103 & 202 \\
\hline $\mathrm{Be}$ & 2 & 2 & $<1$ & 2 & 3 & 2 & 2 & $<1$ & $<1$ & $<1$ \\
\hline Co & 56,2 & 60,6 & 50,3 & 39,2 & 29,4 & 30 & 33 & 19,6 & 29,1 & 1,3 \\
\hline Cs & 1,6 & 1,5 & 0,9 & 0,6 & 1,8 & 4,3 & 0,2 & 0,8 & 0,3 & 0,9 \\
\hline $\mathrm{Ga}$ & 21,8 & 16,9 & 19,6 & 17,3 & 18,3 & 16,1 & 21,5 & 18,6 & 22,5 & 20 \\
\hline $\mathrm{Hf}$ & 2,9 & 2,5 & 2,1 & 2,4 & 3,1 & 3,2 & 4,7 & 2,5 & 2,9 & 8,5 \\
\hline $\mathrm{Nb}$ & 4,8 & 3,6 & 3 & 4,3 & 7,4 & 5,9 & 7,5 & 3,6 & 4,2 & 13,6 \\
\hline $\mathrm{Rb}$ & 13,1 & 17,1 & 7 & 11,4 & 21,8 & 33,2 & 1 & 7,4 & 3,8 & 28,5 \\
\hline $\mathrm{Sn}$ & $<1$ & $<1$ & $<1$ & 1 & $<1$ & 1 & 2 & $<1$ & 1 & 3 \\
\hline $\mathrm{Sr}$ & 125 & 102,4 & 183,4 & 180,8 & 233,5 & 177,3 & 212,1 & 379,2 & 347 & 76,4 \\
\hline $\mathrm{Ta}$ & 0,3 & 0,3 & 0,2 & 0,4 & 0,4 & 0,4 & 0,5 & 0,2 & 0,3 & 0,7 \\
\hline Th & 0,9 & 0,5 & 0,6 & 0,6 & 2,2 & 1,8 & 1 & 1,2 & 1,3 & 2,1 \\
\hline $\mathrm{U}$ & 0,3 & 0,1 & 0,1 & 0,1 & 0,8 & 0,7 & 0,2 & 0,5 & 0,4 & 0,7 \\
\hline V & 360 & 346 & 532 & 80 & 166 & 169 & 155 & 171 & 183 & 12 \\
\hline W & 2,2 & 0,5 & 1,3 & 7,9 & 2,3 & 12,4 & $<0.5$ & 1,9 & 1,2 & 2,4 \\
\hline $\mathrm{Zr}$ & 101,1 & 91,7 & 81,4 & 88,8 & 130,4 & 120 & 173,7 & 95,6 & 109,5 & 331,2 \\
\hline \multirow[t]{2}{*}{ Y } & 31,9 & 29,5 & 29,4 & 31,5 & 22,2 & 18 & 55,3 & 16,2 & 17,6 & 78,7 \\
\hline & & & & & \multicolumn{5}{|c|}{ Rare earth elements } & \\
\hline $\mathrm{La}$ & 7,4 & 6,5 & 5,2 & 9 & 17,1 & 16,2 & 12,1 & 10,8 & 11,8 & 23,3 \\
\hline $\mathrm{Ce}$ & 17,8 & 14,2 & 13,7 & 16,7 & 40,9 & 32 & 29,2 & 21,9 & 24,4 & 55,5 \\
\hline $\operatorname{Pr}$ & 2,43 & 2,18 & 1,93 & 2,31 & 5,34 & 3,91 & 4,06 & 2,84 & 3,25 & 7,86 \\
\hline $\mathrm{Nd}$ & 11,9 & 10,4 & 8,9 & 11,3 & 22,8 & 16 & 18,9 & 12,2 & 14,8 & 36,5 \\
\hline $\mathrm{Sm}$ & 3,42 & 3,23 & 3,01 & 3,64 & 5,13 & 3,52 & 6 & 2,8 & 3,35 & 9,89 \\
\hline $\mathrm{Eu}$ & 1,36 & 1,16 & 1,18 & 1,49 & 1,53 & 1,01 & 1,87 & 0,96 & 1,02 & 2,65 \\
\hline $\mathrm{Gd}$ & 4,53 & 4,5 & 4,29 & 4,85 & 4,82 & 3,41 & 8,19 & 2,9 & 3,5 & 11,85 \\
\hline $\mathrm{Tb}$ & 0,84 & 0,8 & 0,75 & 0,89 & 0,69 & 0,53 & 1,46 & 0,49 & 0,54 & 2,16 \\
\hline Dy & 5,35 & 5,31 & 4,97 & 5,43 & 4,01 & 3,03 & 9,33 & 2,89 & 3,09 & 14,01 \\
\hline Ho & 1,18 & 1,2 & 1,05 & 1,17 & 0,79 & 0,65 & 2,12 & 0,63 & 0,62 & 3,15 \\
\hline $\mathrm{Er}$ & 3,49 & 3,47 & 3,28 & 3,73 & 2,3 & 1,83 & 6,06 & 1,67 & 1,77 & 9,55 \\
\hline $\mathrm{Tm}$ & 0,53 & 0,53 & 0,48 & 0,52 & 0,33 & 0,27 & 0,91 & 0,26 & 0,27 & 1,48 \\
\hline $\mathrm{Yb}$ & 3,55 & 3,34 & 3,07 & 3,36 & 2,12 & 1,9 & 5,68 & 1,74 & 1,65 & 9,49 \\
\hline $\mathrm{Lu}$ & 0,58 & 0,51 & 0,49 & 0,56 & 0,31 & 0,3 & 0,9 & 0,27 & 0,26 & 1,52 \\
\hline
\end{tabular}




\section{Discussion}

\subsection{Relative Chronology between the Lithological Formations}

Based on lithological descriptions and crystallization-strain relations, the Birimian formations of the Djarkadougou gold prospect were classified into fourth sets.

The first set consists essentially of andesi-basaltics, andesitic flows, schistosed or sheared amphibolite or amphiboloschists and sub-volcanic rocks (microdiorite and microgabbro). Several types of structures were observed: mylonite foliation and mineral stretch. These structures have been attributed to the D1 phases. This set is older and basis value for the series of belt Houndé. This deformation preceeds an explosive volcanism at the origin of the second set.

The second set includes pyroclastic crystals tuffs composed of rhyolite and dacite as well as tuffaceous projections transformed into orthoschists. It is followed by an volcanic activity; consisting of rhyolitic and dacitic lava. The latter form a third set assumed to small veins with extended clean contacts with their host rocks. The fourth set corresponds to granitic intrusions including tonalite and granite leucocratic inducing in all these previous enclosing a contact metamorphism.

\subsection{Relations between Deformation and Mineralization}

Given the structural evolution of southwestern Burkina Faso, it follows three main deformation phases expressed in the core drilling of Djarkadougou prospect.

The first is a NW-SE compression corresponding to D1 shortening mechanism. The accentuation of the stress will lead to the development of ductile shear zones of NNE-SSW direction, the interfaces between the green rocks and plutonic rocks. On Djarkadougou bore gold mineralization is hosted in greenstone sheared and hydrothermally. Beziat et al. 2008 about metallogeny of gold in Burkina Faso, attributed this type of mineralization to ductile shear D1 phases.

Phase (D2) assigned to the brittle-ductile stage recognized in the area from the compression-transpressional mechanism E-W trending, leading to a shear transcurrent characterized by isoclinally folds development and transverse to the regional cleavage. Milesi et al., 1989 in his study of mineralization in West Africa stressed that the brittle-ductile character and greenschist facies metamorphism are factors favorable to the development of the orogenic gold mineralization. Several authors working on gold mineralization in Burkina-Faso (Beziat \& al.,2008) related them to D2 transcurrent shear zones oriented in following the NE-SW trending. After these authors, the abundance of gold-bearing quartz veinlets in Djarkadougou prospect would be the product of D2 Events. These veins correspond to those intersecting the second generation to the regional S1foliation.

D3 stage just follow D2 phase developed by a N-S compression scheme. This phase is characterized by the development of a cleavage S3 crenulation and minor fractures oriented NW-SE. This last phase affecting the Houndé shear zone develops secondary shear zones that are favorable zones to the movement of fluids remobilising, concentrating and precipitating gold.

The relationship between the structural evolution and gold mineralization that may exist is the structural controls of Djarkadougou prospect. However mineralization is presumed to be controlled together by the structural and hydrothermal alteration, characteristics of orogenic deposit. This type of deposit has been discussed for primary mineralization of Burkina Faso (Beziat \& al. 2008) in particular and Poura Taparko deposits (Sanogo, 1993 Bourges \& al., 1998).

\subsection{Geodynamic Setting}

Geochemical standpoint, basalts compared to neighboring regions show close geochemical signatures of N-MORB type marked with relatively flat spectra. However, they are characterized by very marked Ti anomalies related involving iron-titanium-oxide. These basaltic magmatism related to the type of island arc. Andesites have a calc-alkaline composition and show intra-oceanic subduction zones affinities (Pothin 1993). It then emerges bimodal volcanism also described in the Boundiali area in Ivory Coast, or Perkoa (Napon, 1988), Bouroum (Zonou 1987) and Gaoua areas (Wenmenga \& Affaton 2008). In some cases, as in Boundiali, alkaline magmas are generated in a context of transcurrent faults. This context would probably be the one that prevailed in the setting of post-magmatic phenomena in Djarkadougou sector.

From structural point of view, several studies have been conducted in the greenstone belts in Burkina Faso (Baratoux \& al, 2011; Tshibubudze \& al., 2009) and admit the multiphase character of the shear deformation. The brittle deformations are temporally associated with the late episode of Eburnean D3 tectonic (Béziat \& al., 2008). From field observations made in the study area this was affected by NNE-SSW structural faults trending 
(Metour \& al., 2003) in a sinistral dominance move to. These faults were interpreted as D2-D3 synchronous deformation phases. One can then speculate that the shearing deformations of Djarkadougou are D2-D3 synchronous events Metour \& al., (2003).

\subsection{Hydrothermal Alteration-Deformation Relationship}

The structural synthesis study of Djarkadougou prospect cores highlight N-S $\left(\mathrm{N} 10^{\circ} \mathrm{E}\right)$ shear corridor. The area is marked by a dominant ductile and ductile-brittle subordinated deformation generally NE-SW direction. The relational field between these large areas of deformation and microstructures show a gradual transition (Figure. 13) registered by the tonalitic protholith affected by a variable mylonitisation of increasing degree in relation to the increase of the stress during the deformation process. This case has been described by Sibson (1977) Figure.13.

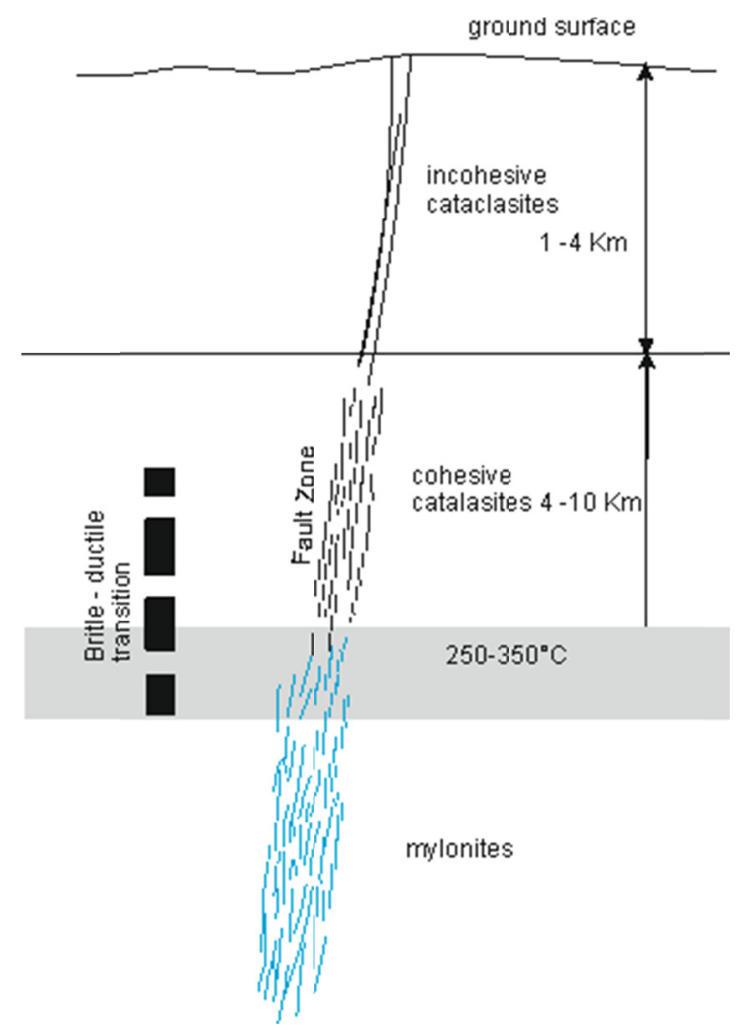

Figure 13. Changes character in fault zones relation with depth (Sibson, 1977)

The transitional zone begins the protomylonitic rocks and mylonite and evolves to ultramylonites whose tonalites are the markers of this progressive deformation. It includes fractures extending obliquely to the axis developed porphyroblasts. These fractures are the main pipe to reduce the size of porphyroblasts and always associated with hydrothermal alteration. Quartz porphyroblasts have various sizes and containing quartz crystal aggregates which sometimes show an undulating extinction and ribbon deformation. The mylonitic zones represent areas of intense deformation, hydrothermal alteration and mineralized area. These areas are characterized by a mylonitic foliation. Pervasive mylonitic Factory is defined by the grinding of the grains, the preferential orientation of chlorite, biotite lamellae, fine aggregate quartz and by quartz and carbonate veins.

\section{Conclusion}

Petrographic study showed that the Djarkadougou prospect is geological based on various formations affected by intense deformation and hydrothermal alteration. They consist of volcanic and volcaniclastic together with andesite lithofacies, of andesi-basalt, acid basic tuffs, breccias, volcano-sediments and terrigenous, metamorphic together with the contact, the mylonite and ultramylonites associated with hydrothermal-rock or metasomatic-rocks and plutonic together mainly composed of gabbro, tonalite, diorite and granites leucocratic. They are affected by strong brittle-ductile deformation due to compression-transpressional steering E-W mechanism thus causing transcurrent shear zones favorable for mineralization deposits. The last event occurring is characterized by the development of secondary shearing and fracturing of competent rocks. It revealed a shear 
zone that promoted through numerous fractures, the circulation of hydrothermal fluids. The relationship between the structural evolution and control of gold mineralization may be the scheme of gold mineralization of Djarkadougou prospect. However mineralization is presumed to be controlled by the structural together with hydrothermal alteration.

\section{Acknowledgements}

This work was carried out under the mining research program on the gold prospect Djarkadougou, permit held by the company OREZONE Inc. Our thanks go particularly to the area of Dera Mr. Moumouni Director Exploration Africa West of the said company for logistics available to us and also to Pr. Wenmenga and Pr Djro lavished their relevant comments and suggestions.

\section{References}

Ada, K., Gampini, S. E., Naba, S., Marquis, P., Lompo, M., Wenmenga, U., Traoré, S. A., \& Ilboudo, H. (2011). The Djarkadougou gold deposit in the Houndé greenstone belt (Burkina-Faso - West Africa): lithological and structural context .Journal des Sciences et Technologies 2011 Vol. $9 n^{\circ} 2$ pp.49-64

Baratoux, L., Metelka, V., Naba, S., Jessell, M. W., Grégoire, M., \& Ganne, J. (2011). Juvenile Paleoproterozoic crust evolution during the Eburnean orogeny $(\sim 2.2-2.0 \mathrm{Ga})$, western Burkina Faso. Precambrian Research 191, pp.18-45.

Bard, J. P. (1974). Remarques à propos de l'évolution géotectonique du Craton Ouest africain en Côte d'Ivoire. C. R.Acad. Sci., Paris, 278, D, 2405-2408.

Bassot, J. P., \& Dommanget, A. (1986). Mise en évidence d'un accident majeur affectant le Protérozoïque inférieur des confins sénégalo-maliens. C.R. Acad. Sci., Paris, II, 302, 1101-1106.

Berthé, D., Choukroune, P., \& Jégouzo, P. (1979). Orthogneiss, mylonite and non-coaxial deformation of granites example of the South Armorican Shear Zone. Journal of Structural Geology 1, pp.31-42.

Beziat, D., Dubois, M., Debat, P., Nikiema, S., Salvi, S., \& Tollon, F. (2008). Gold metallogeny in the Birimian craton of Burkina Faso (West Africa). Journal of African Earth Sciences, 50, 215-233.

Bonkoungou, I. (1994). Le Tarkwaien du sillon de Houndé (Burkina-Faso): Un ensemble volcano-détritique acide calcoalcalin à $2.15 \mathrm{Ga}$. Etude pétrologique, métamorphique et structurale. Univ. Nantes.

Bourges, F., Debat, P., Tollon, F., Munoz, M., \& Ingles, J. (1998). The geology of the Taparko gold deposit, Birimian greenstone belt, Burkina Faso, West Africa. Mineralium Deposita, (1998)33, 591-605

Boynton, W. V. (1984). Geochimitry of the rare earth elements: meteorite studies. In: Henderson P (ed.), Rare earth element geochimitry. Elsevier, 63-114.

Castaing, C., Billa, M., Milesi, J. P., Thielblemont, D., Metour, J. L. E., Egal, E., ... Donzeau, M. (2003). Notice explicative de la carte géologique et minière du Burkina Faso à 1/1 000000 .

ceinture volcanique birimienne de Yako-Batié (Burkina Faso). C.R. Acad. Sci., Paris, 303(2), 19, 1713-1718.

Einsenlhor, B. N., \& Hirdes, W. (1992). The structural development of the early proterozoic Birimian and Tarkwaian rocks of southwest of Ghana, West Africa. Journal of Africain Earth Science. 14, 313-325.

Feybesse, J. L., Milési, J. P., Johan V., Dommanget A., Calvez, J. Y., Boher, M., \& Abouchami, W. (1989). La limite Archéen-Protérozoïque inférieur de l'Afrique de l'Ouest: une zone de chevauchement majeur antérieure à l'accident de Sanssandra : l'exemple des régions d'Odienné et de Touba (Côte d'Ivoire). C.R. Acad. Sci., Paris, II, 309, 1847-1853.

Hirdes, W., Davis, D. W., \& Eisenlohr, B. N. (1992). Reassessment of Proterozoic granitoidages in Ghana on the basis of $\mathrm{U} / \mathrm{Pb}$ zircon and monazite dating. Precambrian Research, 56, 89-96.

Hirdes, W., Davis, D. W., Lüdtke, G., \& Konan, G. (1996). Two generations of Birimian (Paleoproterozoic) volcanic belts in northeastern Côte d'Ivoire (West Africa): consequences for the "Birimian controversy". Precamb Res., 80, 173-191.

Huot, D., Sattran, V., \& Zida, P. (1987). Gold in Birimian greenstone belt of Burkina Faso, West Africa. Economic Geology, 82, 2033-2044.

Irvine, T. N., \& Baragar, W. R. A. (1971). A guide to the chemical classification of the common volcanic rocks. Can. J. Earth Sci., 8, 523-548.

Lapworth, C. (1885). The Highland controversy in British geology; its causes, course and consequence. Nature, 


\section{$32,558-559$.}

Ledru, P., Milési, J. P., Vinchon, C., Ankrah, P., Johan, V., \& Marcoux, E. (1988). Geology of the Birimian series of Ghana. In: Abstr. Int. Conf. and Workshop on the Geology and Exploration in Ghana and in selected other Precambrian Terrains. 75 th Anniversary, Ghana Geol. Surv. Dept. Accra Ghana, 26-27.

Ledru, P., Pons, J., Feybesse, J. L., Dommanget, A., Johan, V., Diallo, M., \& Vinchon, C. (1989). Tectonique transcurrente et évolution polycyclique dans le Birimien, Protérozoïque inférieur du Sénégal-Mali (Afrique de l'Ouest). Comptes Rendus Académie des Sciences, Paris, 308, série, 2, 117-122.

Lemoine, S. (1982). Le décrochement ductile de Brobo, un linéament éburnéen majeur, son rôle possible dans l'orogenèse éburnéenne en Côte d'Ivoire. C.R. Acad. Sci., Fr., 295(2), 601-606.

Lemoine, S. (1988). Evolution géologique de la région de Dabakala (NE de la Côte d’Ivoire) au Protérozoïque inférieur. Doctorat ès Sciences, Univ. Clermont-Ferrand, $388 p$.

Liégeois, J. P., Claessens, W., Camara, D., \& Klerkx, J. (1989). The Eburnean orogeny north of Man shield (South Mali): Geology, tectonics and geochronology. In terra abstracts 5th meeting of the European Union of Geosciences (EUG. V.), Strasbourg, Fr., 20-23 March, 1, n 1.

Mawer, C. K. (1986). What is a Mylonite? Geosciences Canada, 3, 33-34

Meschede, M. (1986). A method of discriminating between different types of mid-ocean ridge basalts and continental tholeiites with the Nb-Zr-Y diagram. Chem. Geol., 56, 207-218.

Metour, J. L. E., Chevremont, P., Donzeau, M., Egal, E. (BRGM), Thieblemont D., ... Tegyey M. (2003). Carte géologique du Burkina-Faso à 1/200 000; Feuille Houndé.

Milesi, J. P. (1989). West Africa gold deposits in their lower Proterozoïc lithostructural setting. Chronique Recherche Minière, 497, 3-98.

Milési, J. P., Diallo, M., Feybesse, J. L., Keita, F., Ledru, P., Vinchon, C., \& Dommanget, A. (1986). Caractérisation lithostructurale de deux ensembles successifs dans les séries birimiennes de la fenêtre de Kédougou (Sénégal-Mali) et du Niandian (Guinée): implications gîtologiques. Publications Occasionnelles CIFEG, Paris, 10, 113-121.

Milési, J. P., Feybesse, J. L., Pinna, P., Deschamps, Y., Kampunzu, H., Muhongo, S., ... Heinry, C. (2004). Geological map of Africa 1:10,000,000, SIGAfrique project. In: 20th Conference of African Geology, BRGM, Orléans, France, 2-7 June, http://www.sigafrique.net (last accessed 14/12/2010).

Mullen, E. D. (1983). MnO/TiO2 /P2O5: a minor element discriminant for basaltic rocks of oceanic environments and its implicatiors for petrogeneiss. Earth Planet, Sci, Lett., 62, 25-34.

Napon, S. (1988). Le gisement d'amas sulfuré ( $\mathrm{Zn}-\mathrm{Ag}$ ) de Perkoa dans la province du Sangyé (Burkina-Faso-Afrique de l'Ouest). Cartographie. Etude pétrographique, géochimique et métallogénique. Thèse Univ. Franche-Comté

Oberthür, T., Vetter, U., Davis, D. W., \& Amanor, J. A. (1998). Age constraints on gold mineralization and Paleoproterozoic crustal evolutionin the Ashanti belt of southern Ghana: Precambrian Research, 89, 129 143.

Ouedraogo, M. F. (1987). Cartographie minérale et implications métallogéniques au Burkina-Faso. Thèse Doct. $3^{\mathrm{e}}$ cycle, Univ. Orléans, Fr., 234 p.

Ouedraogo, M. F., \& Prost, A. E. (1986). Mise en évidence des relations entre schistosités et plissements dans la

Pothin, K. B. K. (1993). Un exemple de volcanisme du Protérozoïque inférieur en Côte d'Ivoire: zone de subduction ou zone de cisaillement? Journal of African Earth Sciences, 16(4), 437-443.

Sanogo, A. D. (1993). Conditions structurales et minéralogiques du filon aurifère de Poura (Province du Mouhoun, Burkina Faso). Thèse Univ. Orléans.

Sattran, W., Droege, B., Franceschi, G., Kaboré, J., Lointier, D., Sanou, T., ... Telleen K. (1984). Carte métallogénique des zones birrimiennes de Boromo et de Houndé à $1 / 400000^{\mathrm{e}}$.

Sibson, R. H. (1977). Fault rocks and fault mechanisms. J. Geol Soc. London, 133, 191-213

Sibson, R. H. (1990). Faulting and fluid flow. In: Nesbitt BE (ed) M.A.C. Short course on Fluids in tectonically active regimes of the continental crust. Mineralogical Association of Canada Short Course Handbook, 18, 92-132. 
Spry, A. (1969). Metamorphic textures. Pergamon, London, 350p.

Taylor, P. N., Moorbath, S., Leube, A., \& Hirdes, W. (1992). Early Proterozoic crustal evolution in the Birimian of Ghana: constraints from geochronology and isotope geochemistry. Precambrian Research, 56, 97-111.

Taylor, S. R., \& McLennan, S. M. (1985). The continental crust; its composition and evolution. Blackell, Oxford.

Tshibubudze, A., Hein, A. A., \& Marquis, P. (2009). The Markoye shear zone in NE Burkina Faso. Journal of African Earth Sciences, 55, 245-256.

Vidal, M., \& Alric, G. (1994). The Paleoproterozoïc (Birimian) of Haute-Comoé in the West African craton, Ivory Coast: A transtensional back-arc basin. Precambrian Research volume 65, pp. 207-229.

Vidal, M., \& Guibert, P. (1984). Un nouveau décrochement ductile nord-sud dans le Birimien d'Afrique de l'Ouest. Le couloir de cisaillement senestre de Wango Fitini (Côte d'Ivoire). C. R. Acad. Sci., Fr., 229(2), n $15,1085-1090$.

Vidal, M., Delor, C., Pouclet, A., Siméon, Y., \& Alric, G., (1996). Evolution géodynamique de l'Afrique de l'Ouest entre 2,2 Ga et $2 \mathrm{Ga}$ : le style archéen des ceintures vertes et des ensembles sédimentaires birimiens du Nord-Est de la Côte d'Ivoire. Bulletin de la Société géologique de France, 167(3), 307-319.

Wenmenga, U., \& Affaton, P. (2003). Les anomalies géochimiques (Pb-Zn-Cu) du district métallogénique de la région de Gaoua, ceinture Birimienne de Poura Burkina-Faso. Journal of Mining and Geology. Nigeria Mining and Geosciences society (NMGS)-Printed in Nigeria, 39(1), 29-38.

Wise, D. U., Dunn, D. E., Engeder, J. T., Geiser, P. A., Hatcher, R. D., Kish, S. A., Odom, A. L., Shamel, S., (1984). Fault related rock: Suggestion for terminology. Geology, 12, 391-394.

Zonou, S. (1987). Les formations leptyno-amphibolitiques et le complexe volcanique et volcano-sédimentaire du Protérozoïque Inférieur de Bouroum-Nord (Burkina-Faso Afrique de l'Ouest): Unpublished Ph.D. thesis, Université de Nancy, 294 p.

\section{Copyrights}

Copyright for this article is retained by the author(s), with first publication rights granted to the journal.

This is an open-access article distributed under the terms and conditions of the Creative Commons Attribution license (http://creativecommons.org/licenses/by/4.0/). 